\title{
Permeability of rock discontinuities and faults in the Triassic Sherwood Sandstone Group (UK): insights for management of fluvio-aeolian aquifers worldwide
}

\author{
Giacomo Medici ${ }^{1} \cdot$ L. Jared West ${ }^{1} \cdot$ Nigel P. Mountney $^{1} \cdot$ Michael Welch $^{2}$ \\ Received: 26 January 2019 / Accepted: 31 August 2019/Published online: 29 October 2019 \\ (C) The Author(s) 2019
}

\begin{abstract}
Fluvio-aeolian sedimentary successions host groundwater aquifers at shallow depths $(<\sim 0.15 \mathrm{~km})$, which overlie geothermal and shale-gas reservoirs, and nuclear waste repositories at intermediate depths $(\sim 0.15-2.0 \mathrm{~km})$. Additionally, such deposits represent petroleum reservoirs at greater depths $(\sim 2.0-4.0 \mathrm{~km})$. The need to improve conceptual understanding of the hydraulic behaviour of fluvial-aeolian sandstone successions over a large depth interval $(\sim 0-4 \mathrm{~km})$ is important for socio-economic reasons. Thus, the hydraulic properties of the Triassic Sherwood Sandstone aquifer in the UK have been reviewed and compared to similar fluvioaeolian successions. The ratio between well-scale and core-plug-scale permeability $\left(K_{\text {well-test }} / K_{\text {core-plug }}\right)$ acts as a proxy for the relative importance of fracture versus intergranular flow. This ratio (which typically varies from $\sim 2$ to 100 ) indicates significant contribution of fractures to flow at relatively shallow depths $(<\sim 0.15 \mathrm{~km})$. Here, permeability development is controlled by dissolution of calcite-dolomite in correspondence of fractures. The observed ratio $\left(K_{\text {well-test }} / K_{\text {core-plug }}\right)$ decreases with depth, approaching unity, indicating that intergranular flow dominates at $\sim 1 \mathrm{~km}$ depth. At depths $\geq \sim 1 \mathrm{~km}$, dissolution of carbonate cement by rock alteration due to groundwater flow is absent and fractures are closed. Aeolian and fluvial deposits behave differently in proximity to normal faults in the Sherwood Sandstone aquifer. Deformation bands in aeolian dune deposits strongly compartmentalize this aquifer. The hydro-structural properties of fluvio-aeolian deposits are also controlled by mineralogy in fault zones. A relative abundance of quartz vs. feldspar and clays in aeolian sandstones favours development of low-permeability deformation bands.
\end{abstract}

Keywords Fractured rocks $\cdot$ Sandstone $\cdot$ Fault $\cdot$ Permeability $\cdot$ UK

\section{Introduction}

Fluvial and aeolian deposits commonly form thick sedimentary successions $(>1 \mathrm{~km})$ in basins for which accommodation was generated in response to compressional, strike-slip and extensional tectonics, as well as thermal subsidence (Bosellini 1989; Waugh 1973)_for example, continental deposits of fluvial and aeolian origin represent a part of foreland

Giacomo Medici

g.medici@leeds.ac.uk

1 School of Earth and Environment, The University of Leeds, Leeds LS2 9JT, UK

2 Centre for oil and gas, Technical University of Denmark, Elektovej, 2800 Kgs. Lyngby, Denmark basins such as the fill of the Ainsa Basin in Spain and the Paradox Basin in Utah, USA (Dreyer et al. 1999; Condon 1997). Fluvial sedimentary successions of Upper Cretaceous to Quaternary age characterize transtensional basins associated with the San Andreas strike-slip fault system in northwestern America (Aydin and Nur 1982). Siliciclastic deposits of fluvial and aeolian origin also represent significant components of the fills of rift basins that develop at the initial stage of the Wilson Cycles during supercontinent break-up (Wilson 1963). Examples of such continental deposits are especially well preserved in Permo-Triassic successions due to the initial phase of rifting of Pangaea. These syn-rift deposits are globally widespread, and are represented in North and South America, Europe, Africa, Asia and Australia (Jones et al. 1988; Waugh 1973).

Siliciclastic deposits of continental origin can serve as important hosts for groundwater resources, and geothermal and 
hydrocarbon reservoirs (Aldinucci et al. 2008; Colombera et al. 2019; McKie et al. 2010; Tellam and Barker 2006; Yuan et al. 2015). Mesozoic sedimentary successions of fluvial and aeolian origin host major groundwater aquifers in Europe, as well as in North America (Heinrichs and Udluft 1999; Morris et al. 2006; Olivarius and Nielsen, 2016; Swanson et al. 2006). Assessment of groundwater behaviour at a variety of depths is important in geoscience since the depth of well screens for water abstraction is typically $<100 \mathrm{~m}$ below ground level (BGL) in the vicinity of both European and American industrial cities, and also in rural areas (Tellam and Barker 2006; Worthington et al. 2016). By contrast, depth intervals associated with nuclear waste repositories are typically 200-1,200 mBGL (Schwartz 2012, 2018; Tsang et al. 2012; Voss and Andersson 1993). Furthermore, exploitation of high enthalpy geothermal reservoirs typically involves extraction of fluids at depths ranging from $\sim 700$ to $1,200 \mathrm{~m}$ from sandstone reservoir rocks in areas characterized by a high geothermal gradient $\left(\sim 200^{\circ} \mathrm{C} / \mathrm{km}\right)$, most notably in areas of active tectonic extension and in subduction-related magmatic arcs (Aldinucci et al. 2008; Chiarabba et al. 1995). Additionally, at depths up to $2,000 \mathrm{mBGL}$, siliciclastic aquifers of fluvial and aeolian affinity overlie targets for production of shale gas in NW Europe (Loveless et al. 2018). Nuclear waste repositories have been sited below thick $(\sim 1 \mathrm{~km})$ Triassic sedimentary successions of fluvio-aeolian origin in Great Britain (the main island of the UK) and Czechia (formerly the Czech Republic; Streetly et al. 2000; Witherspoon 1996). For the aforementioned reasons, the economic interest of the energy industry is considerable (and growing) in the depth interval $\sim 0-2,000 \mathrm{mBGL}$ (Ferguson 2012, 2015; Vengosh et al. 2014). Hydrogeological characterisation can provide information on the hydraulic behaviour of geological structures such as faults in fluvial and aeolian siliciclastic aquifers at such depths (Ford and Tellam 1994; Tesmer et al. 2007). Indeed, faults in sandstone influence the potential for upwards transport of contaminants from both nuclear waste repositories and hydraulically fractured reservoirs of shale gas (Bense et al. 2013, 2016; Cai and Ofterdinger 2014; Flewelling and Sharma 2014). Geothermal production wells are planned in correspondence of extensional faults with large damage zones to exploit the property of maximum permeability parallel to the fracture planes (Loveless et al. 2014; Moreno et al. 2018).

The relative importance of fracture vs. intergranular porosity flow is particularly sensitive to depth in siliciclastic deposits. This proportion is strongly related to effective flowing porosity and determines groundwater flow velocities. Indeed, the velocity of solute contaminant transport decreases with an increase in the proportion of matrix with respect to fracture flow (Berkowitz 2002; Freeze 1975; Lemieux et al. 2009; Quinn et al. 2011; Ren et al. 2018; Medici et al. 2019a).
In contrast, residual flow through bedding-plane discontinuities at greater depths $(\sim 150-1,500 \mathrm{mBGL})$ favours horizontal fluxes of contaminants and retards upward migration associated with steeply inclined faults (Wilson et al. 2017). Yet, both core-plug-scale and welltest-scale data are required jointly to effectively quantify the impact of geological heterogeneities on flow. To date, such multi-scale studies have focussed primarily on fluvial deposits in specific depth intervals (e.g., Corbett et al. 2012; Medici et al. 2016, 2018; Zheng et al. 2000, 2003). However, this work reviews the multi-scale properties of both deposits of aeolian and fluvial origin buried up to $\sim 4 \mathrm{~km}$ depth.

Previous reviews on the multi-scale properties of fluvial and aeolian successions focus at depths $<\sim 150 \mathrm{mBGL}$ (Allen et al. 1997; Tellam and Barker 2006), or on the effect on flow of the sedimentary heterogeneities to guide hydrocarbon exploration on optimization of oil recovery (Medici et al. 2019b). The petrohydraulic properties of the Triassic fluvio-aeolian deposits of Great Britain have been reviewed by Medici et al. (2019b) in relation to sedimentological factors including reconstructed palaeoclimate and depositional palaeoenvironment. By contrast, this review focuses on the flow behaviour of mechanical discontinuities of primarily tectonic origin. The absence of significant effects relating to the Alpine orogenesis phase in the Triassic continental successions of NW Europe favours hydraulic characterization of normal fault-related structures (open fractures, cataclasite, deformation bands), together with bedding plane fractures and high angle-inclined joints (Chadwick 1997; Allen et al. 1998; Odling et al. 1999; Gillespie et al. 2001; Hitchmough et al. 2007; Wealthall et al. 2001). Notably, the UK Sherwood Sandstone Group (Fig. 1a-c) in NW Europe represents a continental succession present in a rift setting. This succession is here specifically selected for review of the multi-scale properties of fluvio-aeolian sandstones because a large amount of borehole information is published (Allen et al. 1997; Nirex 1992a, b; 1993a, b, c; 1996a, b). A diverse suite of background hydrogeological data (e.g., matrix porosity and permeability tests, flow logging, packer and pumping tests) is available for this Triassic succession for the following reasons: (1) it represents the second most important UK aquifer in terms of volume of abstraction (Abesser and Lewis 2015; Smedley and Edmunds 2002); (2) it comprises the bedrock of large industrial cities such as Birmingham, Liverpool and Manchester (Tellam and Barker 2006); and (3) hydraulic characterization for the proposed Sellafield nuclear waste repository has provided data associated with a wide range of burial depths $(0-1,200 \mathrm{mBGL}$; Medici et al 2018). The multi-scale properties of the Triassic Sherwood Sandstone Group in the UK are tested against similar fluvioaeolian aquifers (Permian Penrith and Triassic Stuttgart Sandstone formations) and reservoirs (Jurassic Nugget and Ness and Miocene Mae-Taeng Sandstone formations) throughout the world (Bennet and Clark 1985; Price et al. 1982; Zheng 

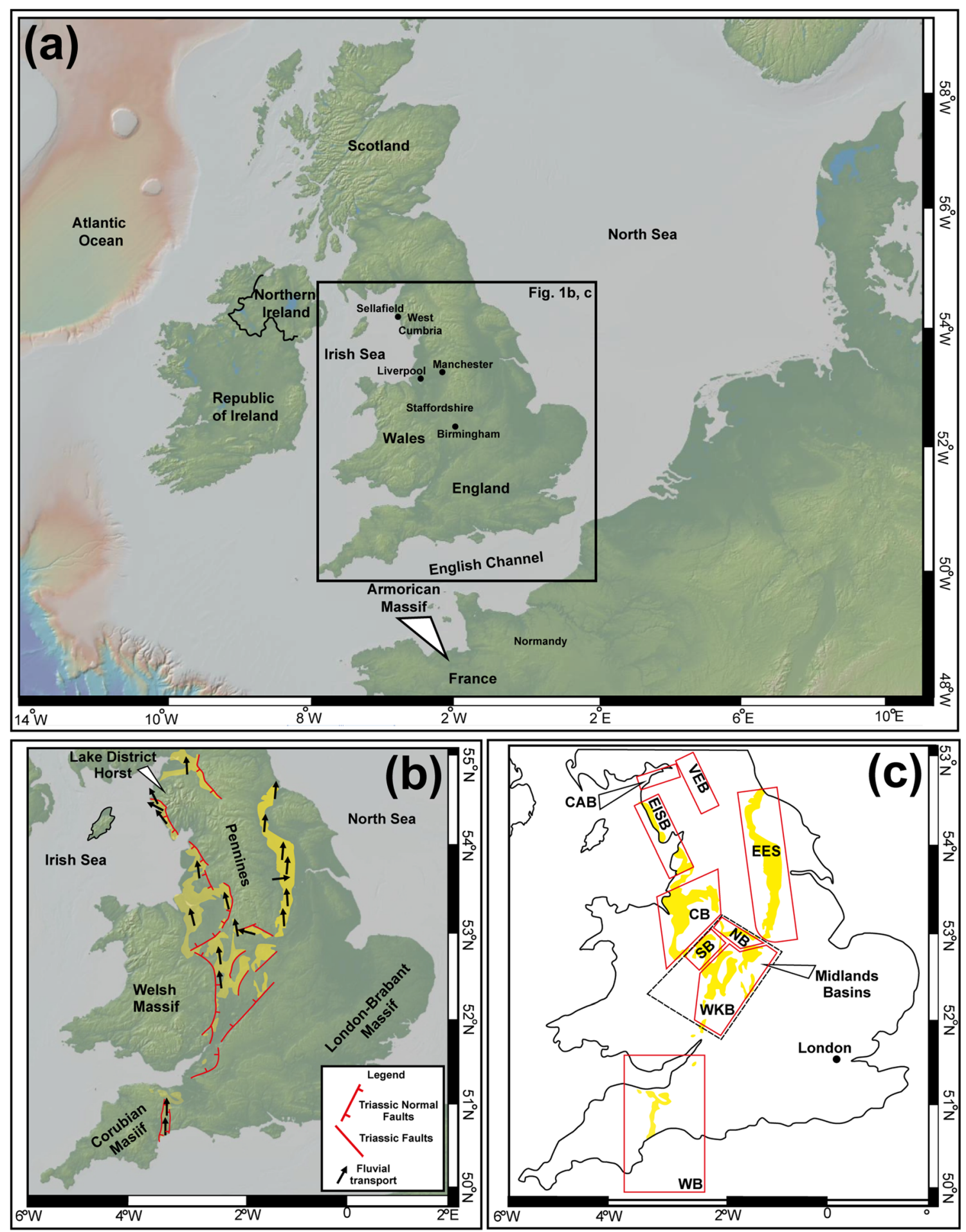

Fig. 1 Triassic siliciclastic deposits of the Sherwood Sandstone Group (in England and Wales, UK) with a background of topography (base map from GeoMappApp 2019). a Armorican Massif in the context of NW Europe; b Fluvial palaeocurrents, Triassic basins (yellow shade) and the Pennines hills (redrawn from Medici et al. 2019b); c Triassic basins

et al. 2000, 2003). This comparison has enabled a review of hydraulic data at the core- and well-test-scale up to depths of $\sim 4 \mathrm{~km}$, typical for hydrocarbon reservoirs. (yellow shade) in Great Britain (redrawn from Wakefield et al. 2015): Worcester (WKB), Staffordshire (SB), Needwood (NB), eastern England Shelf (EES), Cheshire (CB), Eastern Irish Sea (EISB), Vale of Eden (VEB), Wessex (WB) and Carlisle (CAB) basins

The fundamental aim of this research is to establish the role of a range of geological discontinuities (bedding plane fractures, open fractures and deformation bands) vs. the 
intergranular porosity in a broad depth range of crucial interest for energy industry $(\sim 0-4 \mathrm{~km})$. Specific research objectives are as follows: (1) to document the processes that control a reduction of fracture flow and permeability with increasing depth in fluvio-aeolian successions; (2) to propose a specific hydro-structural conceptual model for the siliciclastic deposits of the Sherwood Sandstone Group; and (3) to identify future research needs on the hydro-mechanical behaviour of fault zones in fluvio-aeolian deposits.

\section{The UK Triassic Sherwood Sandstone aquifer}

\section{Geological framework}

The Triassic Sherwood Sandstone Group ( 235-251 Myr, Induan-Ladinian age) comprises a continental sedimentary succession accumulated in a series of sedimentary basins developed in the interior of the Pangaea supercontinent as a consequence of the phase of rifting that preceded the opening of the Atlantic Ocean (Brookfield 2008; Chadwick 1997). The sediments of the Sherwood Sandstone Group have long been ascribed to a mixed aeolian and fluvial origin (Thompson 1970; Holliday et al. 2008; Mountney and Thompson 2002; Newell 2018). Fluvial deposits have been related to a major and long-lived braided fluvial system that was present in much of the Triassic realm of Great Britain (Thompson 1970; McKie and Williams 2009). Indeed, the Triassic fluvial deposits of the Sherwood Sandstone Group are dominated by accreting barform deposits characterized by the coupling of low spread of foreset cross-dip azimuths, and indicative of bifurcation of flow around mid-channel longitudinal bars (Brookfield 2004; Steel and Thompson 1983; Medici et al. 2015; Wakefield et al. 2015). Such characteristics are typical of braided fluvial systems (Colombera et al. 2012, 2019; Colombera and Mountney 2019). Overall, the assemblage of lithofacies present in the succession demonstrates accumulation of a fluvial system developed under the influence of an arid to semi-arid climatic regime, which characterized the Mesozoic basins in England and SW Scotland (Fig. 1a) during much of the Triassic (Brookfield 2004, 2008; Meadows 2006; Schmid et al. 2006).

Extensional tectonic events created horst and graben structures in NW Europe during the Permo-Triassic (Fig. $1 \mathrm{~b}, \mathrm{c})$. Morpho-structural highs in Great Britain served as a major source of sediment for fluvial systems. The principal sediment source of these fluvial systems of Triassic age is represented by the Armorican Massif in northern France (McKie and Williams 2009; Medici et al. 2019b). Extensional tectonics continued after the Permo-Triassic climax and continued to affect basins in England throughout much of the Jurassic and Cretaceous (Chadwick and Evans 1995; Chadwick 1997). Since that time, NW
Europe underwent uplift during the Cenozoic, in response to vertical lithospheric rebound, related either to the seafloor spreading or to the transit underneath the European Plate of a lighter and buoyant asthenosphere (Carminati et al. 2009; Hillis et al. 2008). This Cenozoic lithospheric uplift encouraged the development of high-angle $\left(70-90^{\circ}\right)$ inclined stratabound joints (sensu Odling et al. 1999) which terminate in correspondence of the bedding fractures. Such subhorizontal discontinuities arise from the reactivation of the bedding planes. Stratabound joints and bedding plane fractures, which pervade much of the Sherwood Sandstone Group succession, are related to the unloading due to removal of overlying strata as consequence of uplift and exhumation (Gillespie et al. 2001; Kortas and Younger 2013; Hitchmough et al. 2007).

The deposits of the Sherwood Sandstone Group represent the exhumed fill of a suite of sedimentary basins in Great Britain (Fig. 1c). The succession accumulated in a series of Permo-Triassic basins: in the West Midlands of England are the Staffordshire, Needwood and Cheshire basins; in northwest England are the eastern Irish Sea and Vale of Eden basins; and at the border between England and Scotland is the Carlisle (or Solway) basin. All of these basins represent half graben-type rift basins (Chadwick et al. 1994; Chadwick 1997); however, in southern England, the Wessex and the Worcester basins are symmetric grabens bounded at both margins by major normal faults (Newell 2018). The exception to the dominant rift-related type of basin formation in the Triassic of the UK is the eastern England Shelf, which is a shelf-edge-type basin that is not bounded by extensional faults and did not experience rifting (Burley 1984; Wakefield et al. 2015); here, subsidence was driven by lithospheric cooling or sediment compaction (Medici et al. 2015).

\section{Lithofacies associations}

In all the Triassic basins of England, the basal part of the Sherwood Sandstone Group is characterized by fluvial deposits, which are dominated by channel-fill architectural elements (Fig. 2; Ambrose et al. 2014; Miall 1996). The fluvial palaeocurrents dip towards north as a consequence of the principal sediment source which is represented by the Armorican Massif in northern France (Fig. 1a). An overall northward decrease in mean grain-size and maximum clast-size characterizes the fluvial deposits of the Sherwood Sandstone Group, reflecting the increasing distance from the fluvial sediment source (McKie and Williams 2009; Smith 1990). Fluvial deposits of the Lower Triassic generally pass from conglomerates (LA1 Lithofacies Association 1; Fig. 3a) with interbedded pebbly sandstone in the Wessex, Worcester, Staffordshire, Needwood, Cheshire and southern eastern England Shelf basins, to medium- to fine-grained sandstone (LA2 Lithofacies Association 2; Fig. 3b) in the northern part of the eastern 


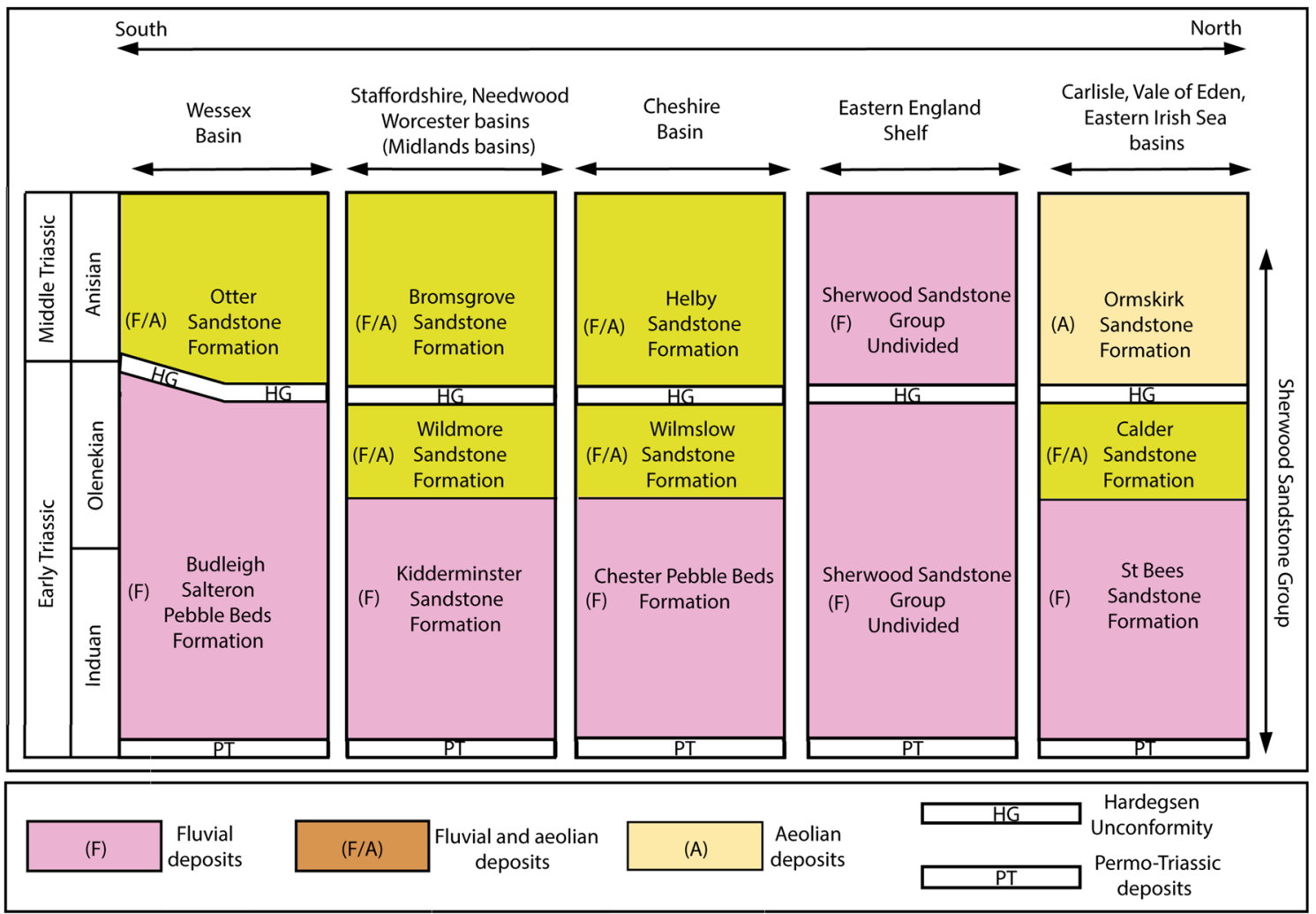

Fig. 2 Litho-stratigraphic scheme and nomenclature of the Triassic succession in sedimentary basins of Great Britain (based on Ambrose et al. 2014; Hounslow et al. 2017, Newell 2018; Medici et al. 2019b; Worden et al. 2016)

England Shelf, eastern Irish Sea Basin, Vale of Eden and Carlisle basins (Ambrose et al. 2014; McKie and Williams 2009; Medici et al. 2019b.

The Sherwood Sandstone Group passes upward into increasingly sand-prone deposits, which are characterized by progressively more abundant facies of exclusively aeolian origin (LA3 Lithofacies Association 3; Figs. 2, 3c, 4d). Several authors have identified a general northward increase in the proportion of aeolian vs. fluvial facies from the upper part of the Sherwood Sandstone Group (Brookfield 2004, 2008; McKie and Williams 2009). The progressive reduction in the discharge of this Triassic system entering a series of interlinked rift basins (see Fig. 1b,c) may have encouraged aeolian sedimentation, accumulation and preservation in the northern, more distal, basins (Medici et al. 2019b).

Fluvial lithofacies associations are characterized by conglomerate and pebbly sandstone lithofacies (LA1), and sandstone-prone channels interbedded with floodplain mudstone (LA2). However, lithofacies associations of aeolian origin (LA3) are characterized by cross-bedded dune deposits, fine-grained sandstones of damp interdune origin and siltstones of wet interdune origin (Mountney and Thompson 2002). Note that detail of lithostratigraphy, lithofacies arrangements and link with depositional palaeoenvironment of the fluvio-aeolian deposits of the Sherwood Sandstone Group can be found in McKie and Williams (2009) and Medici et al. (2019b).

\section{Mineralogy and diagenesis}

Sandstone deposits of the Sherwood Sandstone Group include a variety of lithic arkoses and quartz arenites, depending on relative abundance of quartz, K-feldspar and plagioclase which represent the principal mineral species. Grains of biotite, mica, illite and chlorite are also abundant in these Triassic sandstone deposits (Bath et al. 1987; Holloway et al. 1989; Ixer et al. 1979; Strong 1993; Turner and Ixer 1977).

Diagenesis has determined the mineralogy of the cement species. Three principal diagenetic events are recognized in the Triassic Sherwood Sandstone Group: (1) early diagenesis, (2) burial diagenesis and (3) syn and post uplift diagenesis (Burley 1984).

The early diagenesis reflects initial deposition in the rift basins of fluvio-aeolian sediments in the Lower Triassic, under the influence of an arid-semiarid palaeoclimate (McKie and Shannon 2011; Medici et al. 2018). Smectite, illite, K-feldspar, calcite, hematite and gypsum precipitated during this early stage (Burley 1984). Then, deposits of the Sherwood Sandstone Group were progressively buried to depths ranging from 1.0 to $3.5 \mathrm{~km}$ in on-shore areas during 


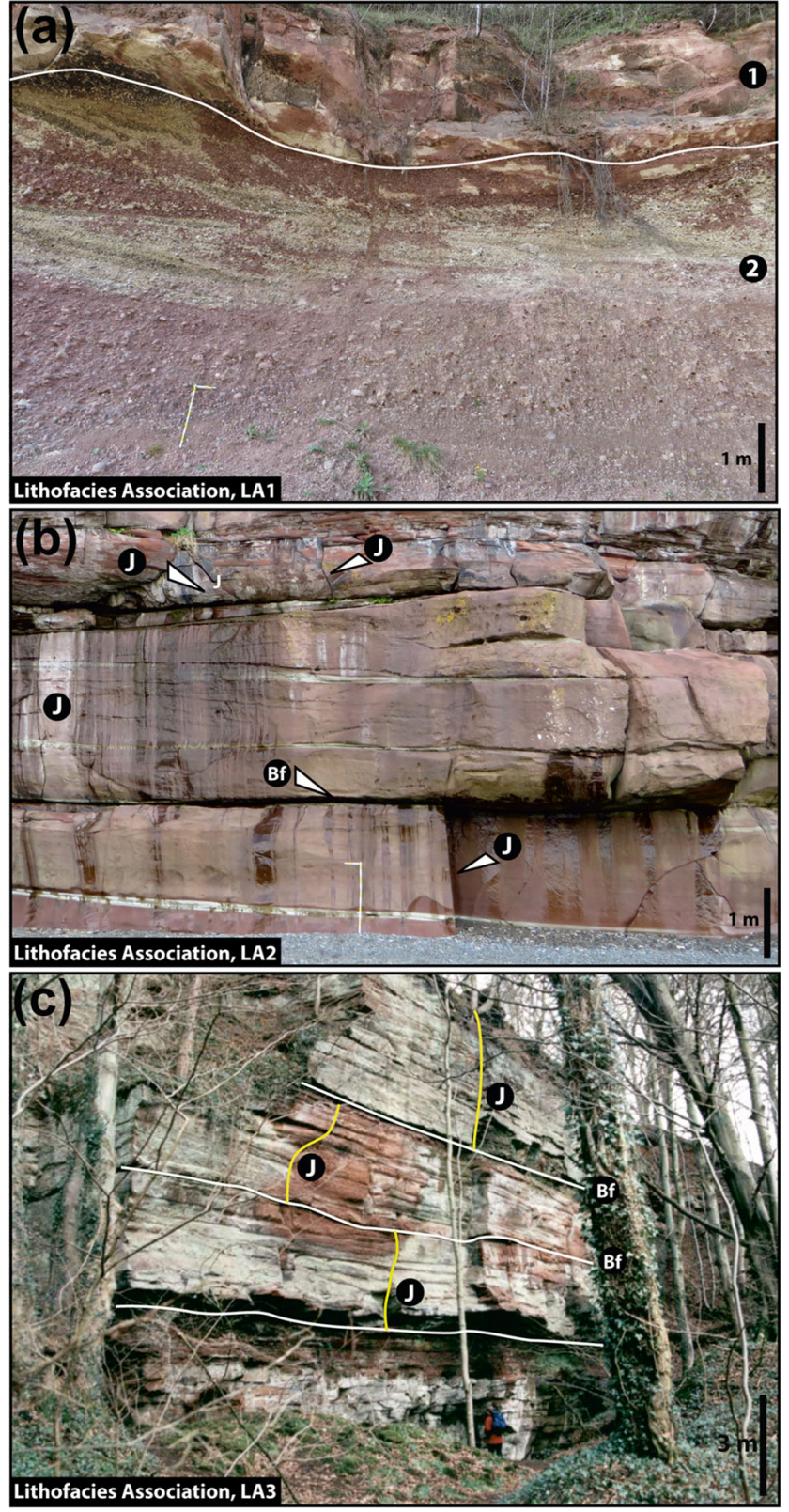

Fig. 3 Outcropping Sherwood Sandstone Group in England and Wales in unfaulted areas (see Fig. 1b,c for location of sedimentary basins). a Kidderminster Sandstone Formation of the Staffordshire Basin with ' 1 ' conglomerate and '2' sandstone lense (Croxden Quarry, Staffordshire), b St Bees Sandstone Formation of the eastern Irish Sea Basin in a cliff section in West Cumbria, 'Bf' bedding plane fractures and ' $\mathrm{J}$ ' stratabound joints (Fleswick Bay, West Cumbria), c Ormskirk Sandstone Formation of the Vale of Eden Basin showing 'Bf' stratabound joints and 'J' bedding parallel fractures (Brampoton Quarry, West Cumbria; Holliday et al. 2008)

the remainder of the Mesozoic. Quartz, dolomite and ankerite precipitated during this period of burial diagenesis (Burley 1984; Strong et al. 1994). The area has been subsequently uplifted during the Cenozoic due to a vertical rebound of the lithosphere (Carminati et al. 2009; Chadwick et al. 1994; Chadwick 1997).
The Cenozoic diagenetic phase syn- and post lithospheric uplift is characterized by removal of calcite, dolomite and evaporite mineral species in the deposits of the Sherwood Sandstone Group (Burley 1984). This is indicated by development of vuggy porosity and cavities detected by petrographic microscope and optical logs, respectively (Strong et al. 1994; Medici et al. 2018). Removal of dolomite and calcite and gypsum cements resulted in increased porosity in the uppermost $\sim 150 \mathrm{~m}$ of the Triassic successions of the Cheshire and Worcester basins (Allen et al. 1997; Tellam and Barker 2006). By contrast, the Sherwood Sandstone Group of West Cumbria shows little change in matrix porosity with depth, as shown by the core data of the proposed Sellafield nuclear waste repository. However, removal of calcite was recognized by optical logs in proximity to fractures at $\sim 100$ mBGL (Medici et al. 2016, 2018).

\section{Mechanical properties and structural style}

The Sherwood Sandstone Group is characterized by a wide range of uniaxial compressive strength values $\left(\mathrm{UCS}_{\text {nat }}\right.$ of 0 $36 \mathrm{MPa}$ ), which describe weak to moderately strong rocks (Charalambous et al. 2012; Hawkins and McConnell 1992; Yates 1992). Uniaxial compressive strengths tested under natural saturation conditions show regional differences across Great Britain (Table 1). The Sherwood Sandstone Group from the Worcester Basin and eastern England Shelf is characterized by $\mathrm{UCS}_{\text {nat }}<22 \mathrm{MPa}$ (Thompson and Leach 1985; Whithworth and Turner 1989). By contrast, the Sherwood Sandstone Group in the subsiding Cheshire and eastern Irish Sea basins shows relatively high $\mathrm{UCS}_{\text {nat }}$ values (17-36 MPa; Table 1).

Development of stratabound and bedding-plane fractures is controlled by the mechanical properties and lithology. Stratabound joints are particularly well developed in the highly mechanically resistant (17-36 MPa of $\mathrm{UCS}_{\text {nat }}$ ) Sherwood Sandstone Group of the eastern Irish Sea and Cheshire basins (Allen et al. 1998; Wealthall et al. 2001; Hitchmough et al. 2007). Additionally, Allen et al. (1998) report that stratabound joints are rare to absent in pebble-bed units of the Kidderminster Sandstone Formation Basin (see lithostratigraphy of the basin in Fig. 2) of the Worcester, Needwood and Staffordshire basins (LA1 in Fig. 3a) due to their low mechanical resistance $\left(\mathrm{UCS}_{\text {nat }}<22 \mathrm{MPa}\right)$.

Lithology in the UK Sherwood Sandstone Group may also play a key role in controlling development of deformation bands vs. open fractures in fault zones. Deformation in fault zones affecting pebble beds (LA1) of the Staffordshire and Needwood basins is concentrated on discrete fault planes and the adjacent fault cores (Fig. 4a; Allen et al. 1998). Fault-related open fractures are particularly well developed in the fluvial St Bees Sandstone Formation (see LA2 shown in Fig. 4b) of West Cumbria (Allen et al. 1998; Knott 1994; 
Fig. 4 Outcropping Sherwood Sandstone Group in England in faulted areas (see Fig. 1b,c for location of sedimentary basins). a Fault plane and core in the Kidderminster Sandstone Formation in the Needwood Basin (Hulme Quarry, Stoke on Trent); $\mathbf{b}$ Extensional fault in the fluvial deposits of the St Bees Sandstone aquifer of the eastern Irish Sea Basin: '1' principal fault plane highlighted by water seepage and ' 2 ' fault related open fractures locally occurring as conjugate sets (Medici et al. 2016); c Swarms and conjugate sets of cataclastic deformation bands in the aeolian deposits of the Helsby Sandstone Formation of the Cheshire Basin (Royden Park, Wirral Peninsula); d Helsby Sandstone Formation of the Cheshire Basin, detail of aeolian dunes and conjugate sets of cataclastic deformation bands (Thurstaston, Wirral Peninsula)
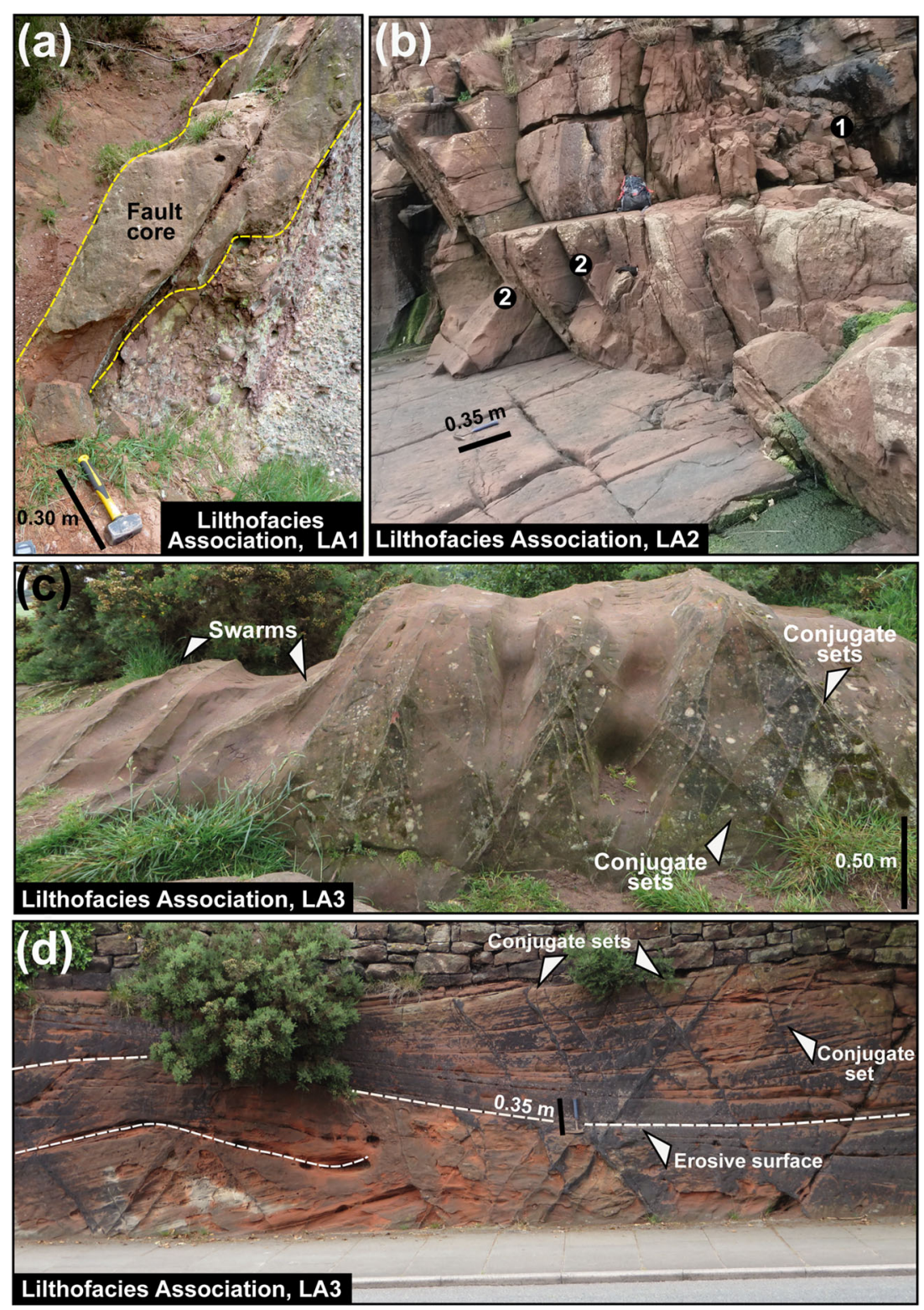

Nirex 1997); however, several authors have highlighted the more abundant occurrence of deformation bands in the aeolian deposits of the Triassic Sandstone in the Wessex and Cheshire basins, UK (Griffiths et al. 2016; Kattenhorn and Pollard 2001). Here, deformation bands form a high-density network occurring either in swarms or conjugate sets (Figs. 4c,d).

Such contrast in structural styles is associated with difference in faulting between predominantly fluvial (eastern Irish Sea Basin) and aeolian (Cheshire basin) deposits that show similar average porosities (20-22\%) in outcrop (Griffiths et al. 2018; Medici et al. 2018). This difference has been related to the contrasting mineralogy of the fluvial St Bees Sandstone Formation (Strong et al. 1994; Knott 1994). The presence of an argillaceous matrix and feldspars in fluvial deposits creates a mechanical anisotropy with respect to the quartzofeldspathic grains, which favours brittle failure at relatively low yield stress (Knott 1994). In contrast, aeolian deposits in the Sherwood Sandstone Group (as in many other aeolian successions worldwide) show a quartzitic matrix, which favours development of deformation bands in fault zones (Fig. 4c,d; Fossen et al. 2007; Knott 1994; Tueckmantel et al. 2012). Although the mineralogy varies between the aeolian dune and the fluvial channel deposits of the Cheshire Basin, both sandstone types are classified as clean (clay $<5 \%$ ) sandstones (Burley 1984; Strong et al. 1994; Tellam and Barker 2006).

The control of lithology on development of open fractures vs. deformation bands in fault zones seems to be a key factor in the UK Sherwood Sandstone Group. Indeed, faults with throw $\sim 10-50 \mathrm{~m}$ in the aeolian deposits of the Cheshire Basin of Merseyside (and northern Cheshire and western Lancashire) are dominated by fine-grained quartz-rich 
Table 1 Geological, mineralogical and mechanical characteristics of selected siliciclastic fluvio-aeolian sandstone types shown in Figs. 7 and 8. $\mathrm{UCS}_{\text {nat }}$ natural uniaxial compressive strength

\begin{tabular}{|c|c|c|c|c|}
\hline Aquifer/reservoir (Age) & Basin & Depositional environment & Cement & $\mathrm{UCS}_{\text {nat }}(\mathrm{MPa})$ \\
\hline \multicolumn{5}{|l|}{ Aquifers } \\
\hline $\begin{array}{l}\text { St Bees Sandstone Formation } \\
\text { (Triassic) }\end{array}$ & $\begin{array}{l}\text { Eastern Irish Sea } \\
\text { Basin, UK }\end{array}$ & Fluvial; Medici et al. (2015) & $\begin{array}{l}\text { Silicate/carbonate; Strong et al. } \\
\text { (1994) }\end{array}$ & $\begin{array}{l}\text { 17-36; Thompson and } \\
\text { Leach (1985) }\end{array}$ \\
\hline $\begin{array}{l}\text { Wilmslow Sandstone } \\
\text { Formation (Triassic) }\end{array}$ & Cheshire Basin, UK & $\begin{array}{l}\text { Aeolian/fluvial; Thompson } \\
\text { (1970) }\end{array}$ & $\begin{array}{l}\text { Silicate/carbonate; Naylor et al. } \\
\text { (1989) }\end{array}$ & 31; West (1979) \\
\hline $\begin{array}{l}\text { Undivided Sherwood } \\
\text { Sandstone Group (Triassic) }\end{array}$ & $\begin{array}{l}\text { Eastern England } \\
\text { Shelf, UK }\end{array}$ & $\begin{array}{l}\text { Fluvial; Wackefield et al. } \\
\text { (2015) }\end{array}$ & Silicate/carbonate; Burley (1984) & $\begin{array}{l}\text { 1-22; Walsby et al. } \\
\text { (1980) }\end{array}$ \\
\hline $\begin{array}{l}\text { Broomsgrove Sandstone } \\
\text { Formation (Triassic) }\end{array}$ & $\begin{array}{l}\text { Worcester Basin, } \\
\text { UK }\end{array}$ & $\begin{array}{l}\text { Fluvial/Aeolian; McKie and } \\
\text { Williams (2009) }\end{array}$ & Silicate/carbonate; Burley (1984) & $\begin{array}{l}\text { 0-16; Whitaker and } \\
\text { Turner (1989) }\end{array}$ \\
\hline $\begin{array}{l}\text { Penrith Sandstone Formation } \\
\text { (Permian) }\end{array}$ & Permian Basin, UK & Aeolian; Waugh (1970) & Silicate/carbonate; Waugh (1970) & $\begin{array}{l}\text { 28-90; Hawkins et al. } \\
\text { (1992) }\end{array}$ \\
\hline Struttgart Formation (Triassic) & $\begin{array}{c}\text { Basin in NE } \\
\text { Germany }\end{array}$ & $\begin{array}{l}\text { Fluvial/Aeolian; Swanson } \\
\text { et al. (2006) }\end{array}$ & $\begin{array}{l}\text { Silicate/anydrite/Carbonate; } \\
\text { Hoholick et al. (1984) }\end{array}$ & 5-12; Yates (1992) \\
\hline \multicolumn{5}{|l|}{ Hydrocarbon reservoirs } \\
\hline Ness Formation (Jurassic) & $\begin{array}{l}\text { Viking Graben, } \\
\text { Norway }\end{array}$ & Fluvial; Ryseth et al. (1998) & $\begin{array}{l}\text { Silicate/carbonate; Ryseth et al. } \\
\text { (1998) }\end{array}$ & NA \\
\hline $\begin{array}{l}\text { Mae Taeng Formation } \\
\text { (Miocene) }\end{array}$ & $\begin{array}{l}\text { Pattani Basin, } \\
\text { Thailand }\end{array}$ & Fluvial; Zheng et al. (2003) & $\begin{array}{l}\text { Silicate/kaolinite/Carbonate; } \\
\text { Trevena and Clark (1986) }\end{array}$ & NA \\
\hline Nugget Sandstone Formation & $\begin{array}{l}\text { Fossil Basin, } \\
\text { Wyoming (USA) }\end{array}$ & Aeolian; Lindquist (1988) & $\begin{array}{l}\text { Silicate/halite/carbonate; James } \\
\text { et al. (1986) }\end{array}$ & NA \\
\hline
\end{tabular}

cataclastic deformation bands (Beach et al. 1997; Griffith et al. 2018). This contrasts with the architecture of faults at the same scale in the Triassic fluvial deposits of the eastern Irish Sea Basin in West Cumbria which are characterized by a much lower density network of deformation bands (Knott 1994; Nirex 1997; Griffiths et al. 2018; Gutmanis et al. 1998). Such deformation bands which are abundant in feldspar, biotite, muscovite and clay minerals, can be classified as phyllosilicate bands (Medici et al. 2018; Strong et al. 1994).

Another important factor that controls occurrence of deformation bands vs. open fractures is represented by the depth of development of such structures. Previous studies have suggested that relatively shallow depths of burial favours development of open fractures and that deformation bands form after early diagenetic stages at burial depths ranging from 2.0 up to $3.5 \mathrm{~km}$ (Fisher and Knipe 1998, 2003; Fossen et al. 2007). The deposits of the Sherwood Sandstone Group reached a burial depth of 3.0-3.5 km in the Early Jurassic time according to apatite fission track subsidence curves, both in the Cheshire Basin of Merseyside and the eastern Irish Sea Basin of West Cumbria (Chadwick et al. 1994; Evans et al. 1993); hence, here, contrasting structural styles of faults of similar scale (i.e. deformation bands versus open fractures) occur in basins characterized by similar maximum burial depths (Evans et al. 1993; Chadwick et al. 1994; Knott 1994; Chadwick 1997). Thus, mineralogy, rather than maximum burial depth, seems to represent a key factor on development of deformation vs. open fractures at least in this case study.

\section{Core-plug-scale properties}

The Sherwood Sandstone Group across Great Britain presents matrix porosity and hydraulic conductivity values ranging from 3 to $38 \%$ and $1.0 \times 10^{-6}$ to $15.0 \mathrm{~m} /$ day, respectively (e.g., Bloomfield et al. 2006; Allen et al. 1997; Pokar et al. 2006).

Daw et al. (1974) tested core plugs of the Sherwood Sandstone Group from quarries in the eastern Irish Sea Basin, Cheshire Basin, Staffordshire Basin and eastern England Shelf. Multi-stage triaxial stress experiments were undertaken to discern the respective roles of open fracture vs. intergranular flow at increasing overburden pressure. Daw et al. (1974) found that fractured plugs are much more permeable than those characterized by intergranular porosity; the average ratio between fractured and unfractured plugs ranges from 2 up to 500 . Additionally, intergranular permeability is only slightly reduced (by 6-20\%) in response to an increase in lithostatic pressure of $7 \mathrm{MPa}$, representing the overburden pressure at approximately $300 \mathrm{~m}$ below the surface. In contrast, the fracture flow component was markedly reduced (by 65-80\%) in experiments that applied the same amount of overburden pressure $(7 \mathrm{MPa})$ to plugs of the Sherwood Sandstone Group that contained single 
fractures (Daw et al. 1974). These core plug-scale experiments highlight the potential impact of joints, beddingplane fractures and fault-related open fractures on conducting flow in the UK Triassic Sandstone at relatively shallow depth $(<\sim 150 \mathrm{mBGL})$.

Deformation bands (Figs. 4c,d) in the Sherwood Sandstone Group are characterized by generally lowporosity (4-8\%) and $10^{-3}-10^{1}$-mm-thick cataclasites (Griffiths et al. 2018; Kattenhorn and Pollard 2001; Tellam and Barker 2006). In fact, porosity collapse processes are common in relatively high-porosity $(>15 \%)$ lithified sandstone as consequence of extension related cataclasis (Al-Hinai et al. 2008; Fisher and Knipe 1998; Fisher et al. 2003; Wong et al. 1997). In this case, the Triassic Sherwood Sandstone aquifer shows a porosity interquartile range of $22-28 \%$ and median of $26 \%$ (Allen et al. 1997; Tellam and Barker 2006).

Core-plug-scale hydraulic conductivity analyses are available for deformation bands of the Sherwood Sandstone Group (Bouch et al. 2006; Medici et al. 2014). These data show how such low-porosity structures possess hydraulic conductivity between 1 and 4 factors of 10 lower than the host rock (Fig. 5). This contrast in permeability between deformation bands $\left(K_{\mathrm{db}}\right)$ and host rock $\left(K_{\mathrm{hr}}\right)$ matches closely or overlaps with results from the Permian Penrith Sandstone (UK), the Jurassic Nugget Sandstone (USA) and the TriassicCretaceous Nubian (Egypt) sandstone formations (Fig. 5; Bouch et al. 2006; Gibson 1998; Medici et al. 2014; Tueckmantel et al. 2010, 2012).

\section{Well-test-scale properties}

Aquifer transmissivities in the Sherwood Sandstone Group show similar values across Great Britain, i.e. median values range from 100 up to $300 \mathrm{~m}^{2} /$ day in the various Triassic basins (Brassington and Walthall 1985; Medici et al. 2016; Tellam and Barker 2006). Such transmissivity values show a positive correlation exclusively for screen lengths $<\sim 120 \mathrm{~m}$. This typically arises, at least in fractured carbonate aquifers, from processes of rock dissolution by groundwater flow in correspondence with fractures which control permeability at relatively shallow depths (< 150 mBGL) (Allen et al. 1997; Lemieux et al. 2006; Odling et al. 2013).

The presence of conductive fractures in the UK Sherwood Sandstone aquifer at depths $<150 \mathrm{~m}$ below the ground surface typically precludes linkage between aquifer transmissivity and lithofacies. For example, the fluvial St Bees Sandstone $(T=20$ $750 \mathrm{~m}^{2} /$ day) and the aeolian Calder Sandstone $\left(T=100-210 \mathrm{~m}^{2} /\right.$ day) aquifers in the eastern Irish Sea Basin, which are characterized by significantly different porosities, and core-plug-scale hydraulic conductivity values, show substantial overlap in transmissivity (Allen et al. 1997; Medici et al. 2016, 2018). High mechanical resistance $\left(\mathrm{UCS}_{\text {nat }}=17-36 \mathrm{MPa}\right)$ favours development of open fractures such as stratabound joints and bedding plane fractures, which dominate flow in the fluvial red-beds of the eastern Irish Sea Basin (Thompson and Leach 1985). Of note, field-scale hydraulic conductivity is $\sim 10^{2}$ higher than plug-scale permeability in the eastern Irish Sea Basin of West Cumbria at shallow depths (< 150 mBGL, Allen et al. 1997).

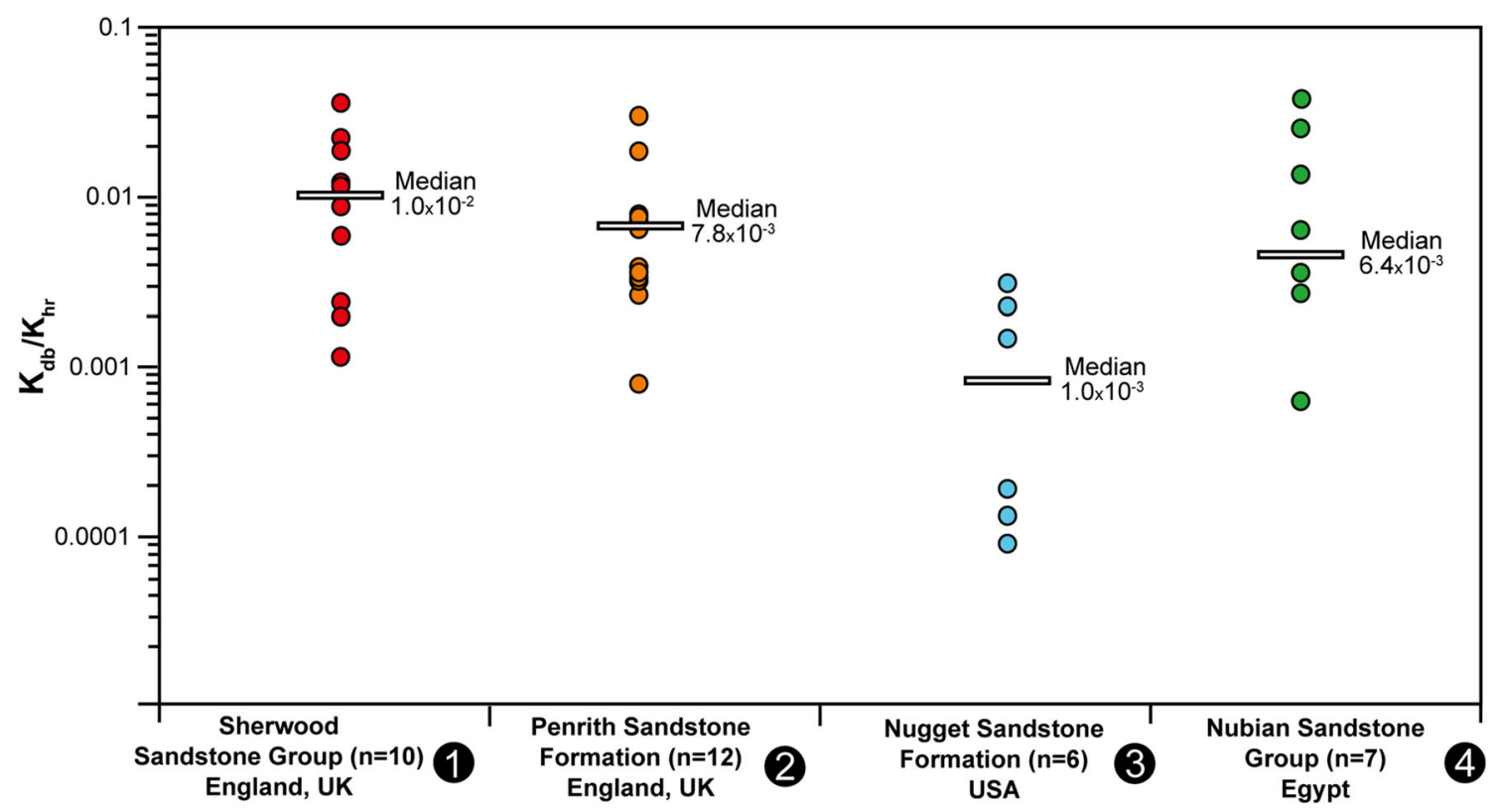

Fig. 5 Deformation band $\left(K_{\mathrm{db}}\right)$ vs. host rock $\left(K_{\mathrm{hs}}\right)$ hydraulic conductivity in the Sherwood Sandstone Group (1, Bouch et al. 2006; Medici et al. 2014) in the Penrith Sandstone Formation (2, Tueckmantel et al. 2012), in

the Nugget Sandstone Formation (3, Gibson, 1998) and in the Nubian Sandstone Group (4, Tueckmantel et al. 2010) 
The studied fluvio-aeolian deposits are highly layered $\left(\sim K_{\mathrm{h}} / K_{\mathrm{v}} \sim 35-150\right)$ at a range of depths $(\sim 0-1.1 \mathrm{~km})$, i.e. the horizontal hydraulic conductivity $\left(K_{\mathrm{h}}\right)$ is much higher with respect to the vertical hydraulic conductivity $\left(K_{\mathrm{V}}\right)$ according to pumping tests (Allen et al. 1997; Streetly et al. 2000). Thus, hydraulic conductivity is defined as the aquifer transmissivity divided by the screen length. The ratio between well-test-derived hydraulic conductivity and values of core-plug hydraulic conductivity is $\sim 4$ in the Sherwood Sandstone aquifer in the Cheshire Basin. This value arises from a well-developed stratabound fracturing network (pervasive due to relatively high mechanical resistance, and permeable as demonstrated by packer tests) coupled with relatively high permeability of the matrix (Brassington and Walthall 1985; Hitchmough et al. 2007). However, the Triassic red-beds of Great Britain show the lowest difference between well- and core-plug hydraulic conductivities $(<2.0)$ in the slowly subsiding eastern England Shelf and Worcester basins (Allen et al. 1997; Ramingwong, 1974). This likely arises because low values of mechanical resistance $\left(\mathrm{UCS}_{\text {nat }}<20 \mathrm{MPa}\right)$ do not permit development of fractures in the latter two sedimentary basins (Walsby et al. 1993; Whithworth and Turner 1989; Yates 1992).

Linkage between well-test transmissivity and presence of faults in the Sherwood Sandstone aquifer is demonstrated in two examples. Faults show high transmissivity in the Triassic fluvial deposits of West Midlands and the eastern Irish Sea Basin, which were tested at relatively shallow (<150 mBGL) and greater (200-400 mBGL) depths (Allen et al. 1997; Medici et al. 2018). The St Bees Sandstone aquifer of the eastern Irish Sea Basin shows how high values of well-test-scale transmissivity and localization of well in-flows up $\sim 1 \mathrm{~km}$ depth are in correspondence with fault damage zones (Gutmanis et al. 1998; Medici et al. 2018; Streetly et al. 2000).

\section{Fluid log, hydraulic head and geochemical data}

Bedding plane fractures, subvertical joints and normal faults are all capable of flow in the Triassic Sherwood Sandstone aquifer of UK (Allen et al. 1997). Indeed, bedding plane discontinuities have been detected as flow pathways at shallow depths $(<\sim 150 \mathrm{mBGL})$ by flow logging under natural conditions in the eastern Irish Sea Basin (Medici et al. 2016), Cheshire (Hitchmough et al. 2007), Worcester (Tellam and Barker 2006) and eastern England Shelf (Rivers et al. 1996). However, high angle $\left(70-90^{\circ}\right)$ inclined joints occasionally support natural flow at the intersection of the bedding planes in the shallow (< 150 mBGL) Sherwood Sandstone aquifer. This has been detected by flow logging under natural conditions only in the relatively highly mechanically resistant
$\left(\mathrm{UCS}_{\text {nat }}=17-36 \mathrm{MPa}\right)$ St Bees Sandstone aquifer of the eastern Irish Sea and Cheshire basins (Medici et al. 2016; Hitchmough et al. 2007).

Normal faults represent tectonic structures influencing fluid flow in different ways, depending on their structural style (Antonellini et al. 1994; Bense et al. 2013; Caine et al. 1996; Fisher et al. 2018). Normal faults in the Triassic continental successions of the UK have been shown to represent both barriers and preferential flow pathways (Tellam and Barker, 2006) from hydraulic head and geochemical data. Extensional faults deforming the aeolian facies of the Wilmslow and Helsby Sandstone formations in the Cheshire Basin (Fig. 6a) were recognized as flow-barriers based on contouring of the water table (Fig. 6b; Seymour et al. 2006) and concentration of chloride in groundwater (Fig. 6c; Mohamed and Worden, 2006), which follow the structural trends. Such hydraulic compartmentalisation is absent in the fluvial deposits of the UK Sherwood Sandstone Group (Allen et al. 1997; Tellam and Barker 2006). Development of a high-density network of deformation bands in the aeolian deposits of the Cheshire Basin explains the barrier behaviour of such normal faults (Beach et al. 1997; Hitchmough et al. 2007; Griffiths et al. 2018). The contrasting hydraulic behaviour of the fluvial and aeolian deposits of the UK Sherwood Sandstone Group in the eastern Irish Sea Basin and Cheshire basins is illustrated schematically in Fig. 7.

\section{Comparison of UK Sherwood Sandstone and analogous successions}

The Sherwood Sandstone Group represents a siliciclastic sedimentary succession deposited in a continental rift setting that can be compared to other sandstone aquifers and hydrocarbon reservoirs of fluvial and aeolian origin (Table 1). For example, the Permian Penrith Sandstone Formation in NW England, the Triassic Stuttgart Formation in Germany, the Jurassic Ness Formation in the Norwegian North Sea and the Miocene Mae Taeng Formation in the Gulf of Thailand are similar to the Triassic Sherwood Sandstone aquifer in that they represent continental syn-rift sedimentary successions characterized by both carbonate and silicate cements (Hoholick et al. 1984; James et al. 1986; Strong et al. 1994; Trevena and Clark, 1986; Nguyen et al. 2013).

In contrast, the Jurassic Nugget Sandstone in the USA and the Triassic-Cretaceous Nubian Sandstone Group in Egypt formations represent a continental succession deposited in nonrifting settings (subsidence is driven by flexure of a foreland basin). Despite this, both the Nugget Sandstone and the Nubian Sandstone successions are deformed by normal faults which accommodate either syndepositional differential subsidence or minor postdepositional episodes of extension (Allen 


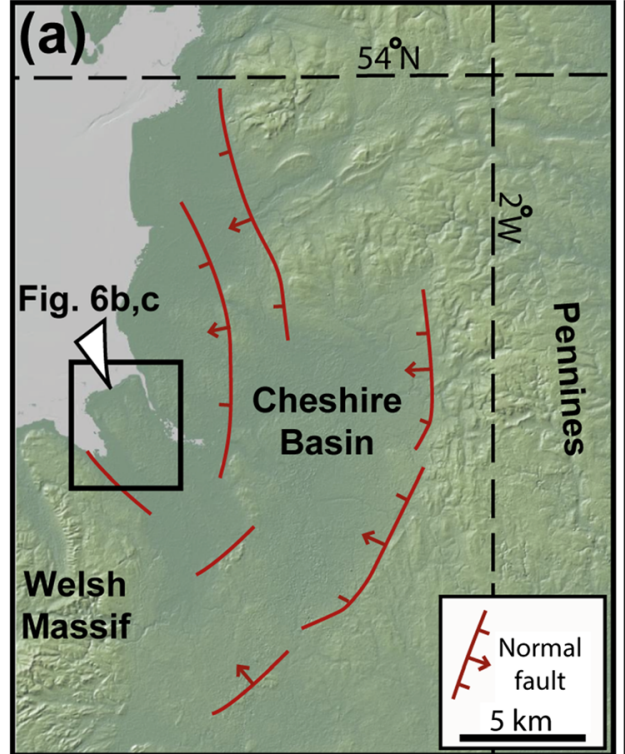

Fig. 6 Aquifer compartmentalization in the UK Sherwood Sandstone Group of the Cheshire Basin. a Central-western England (base map from GeoMappApp 2019); b Contours of the water table in the Wirral-
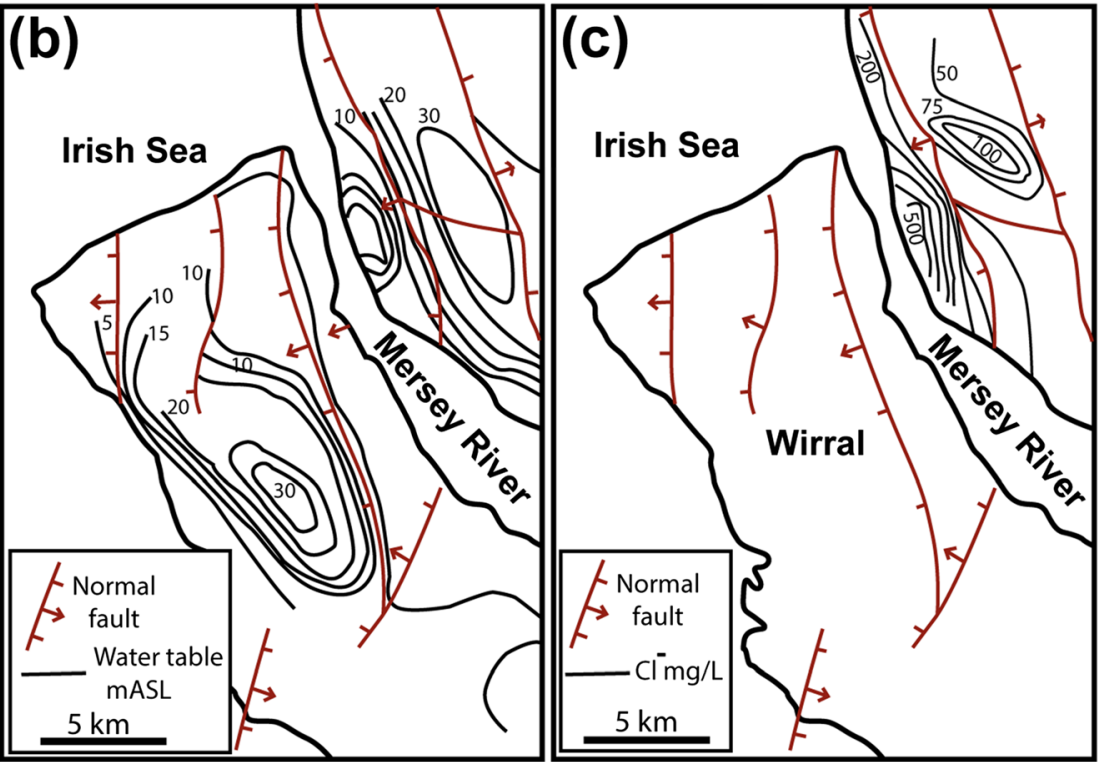

Merseyside area (redrawn from Seymour et al. 2006); c Contours of chloride concentration in the Wirral-Merseyside area (redrawn from Mohamed and Worden 2006) et al. 2000; Aronson and Burtner 1983; Lindquist 1988). Additionally, the latter two continental siliciclastic successions are also similar to the UK Sherwood Sandstone aquifer in terms of mineralogical composition (Table 1).

\section{Synthesis of hydraulic behaviour of continental successions}

A synthesis of information on the hydraulic properties of terrestrial siliciclastic sedimentary successions, from near surface to hydrocarbon reservoir depths, is shown in Figs. 8 and 9.
Well-test-scale hydraulic conductivity (and transmissivity) in siliciclastic continental deposits decreases with depth (Fig. 8), as does the ratio of well-test- and core-plug-scale hydraulic conductivity (Fig. 9). The ratio between well-test- and core plug-scale hydraulic conductivity is typically relatively high $\left(K_{\text {well-test }} / K_{\text {core-plug }}>1.7\right)$ at shallow depths $(<150 \mathrm{mGL})$, indicating the important contribution of fracture flow at such depths (Allen et al. 1997; Brassington and Walthall 1985; Ramingwong 1974; Medici et al. 2016). Additionally, this ratio shows a large variability between the sedimentary successions analysed in Fig. 9-for example, the ratio between
Fig. 7 Conceptual model of hydraulic behaviour of normal faults in the continental successions of the UK Sherwood Sandstone Group

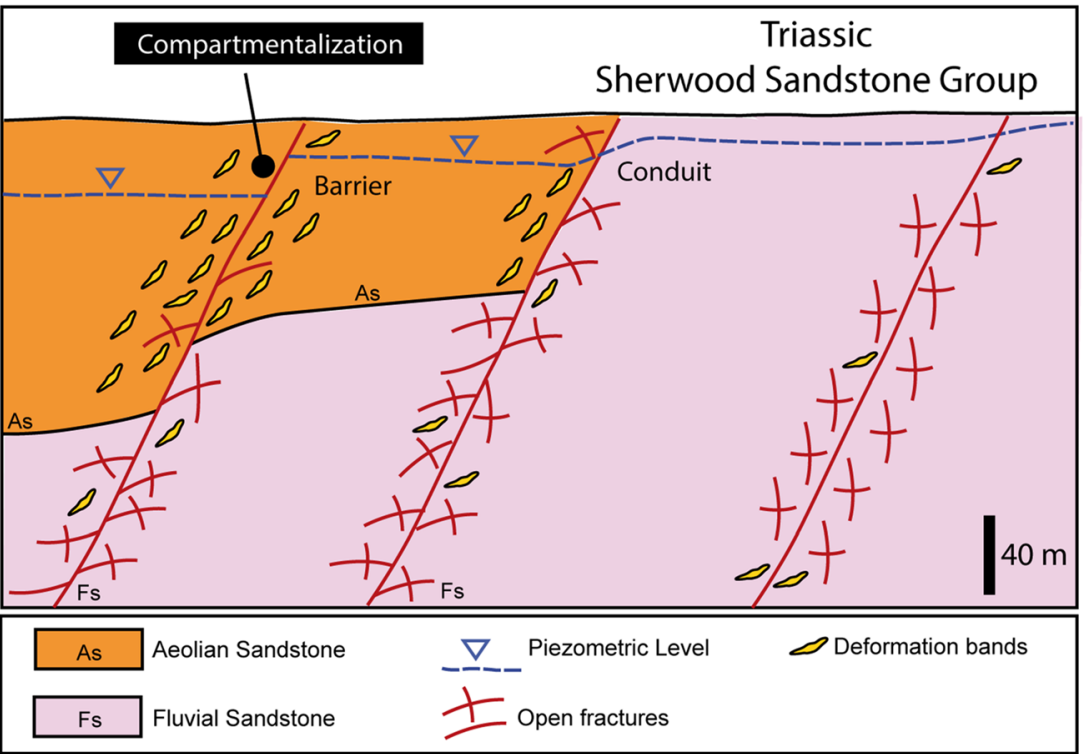


Fig. 8 Median transmissivity $(T)$ and well-test hydraulic conductivity $(K)$ versus depth in continental siliciclastic successions

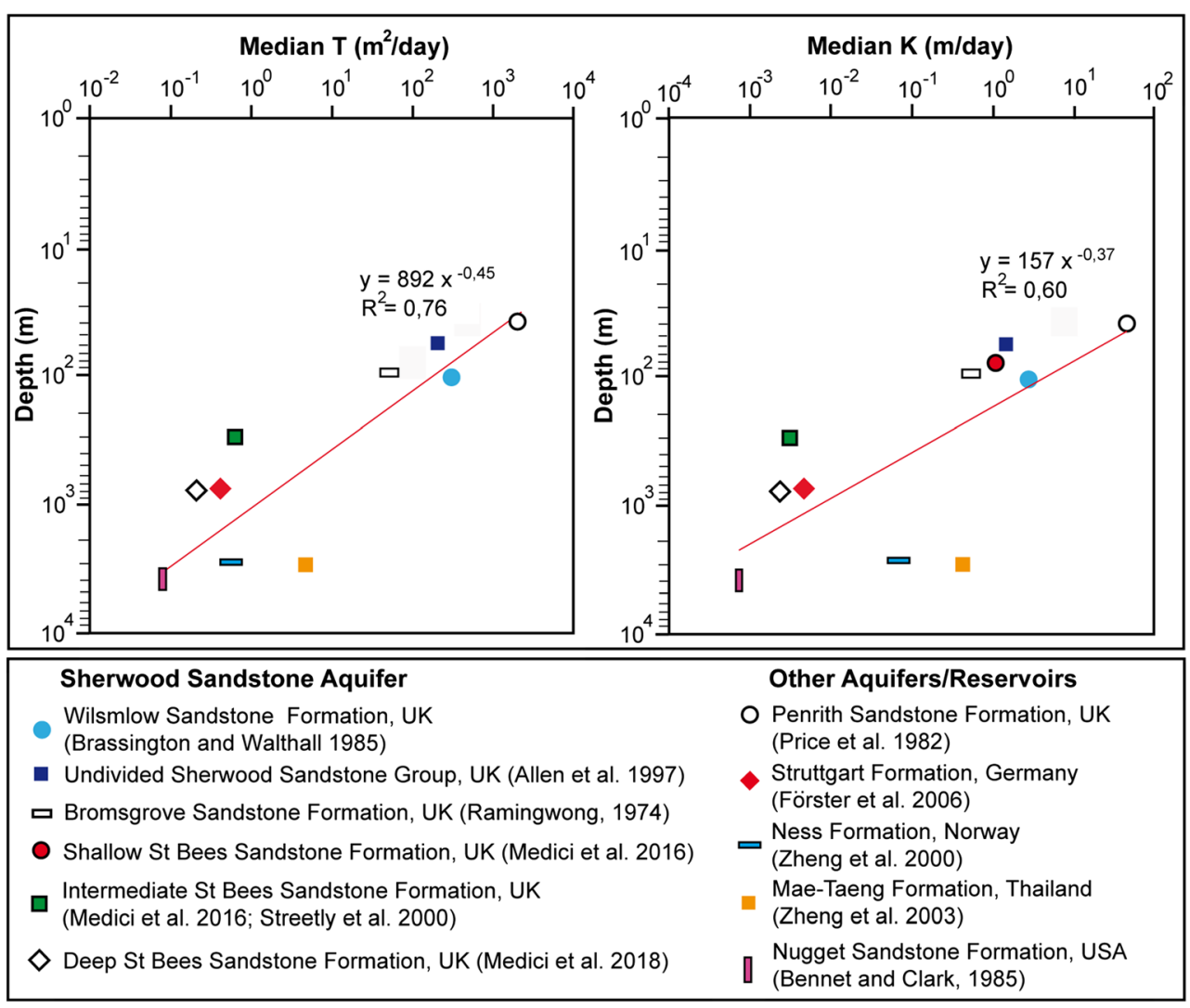

well-test- and core-plug-scale hydraulic conductivity is typically $\sim 4$ in the Penrith Sandstone in NW England and the Sherwood Sandstone Group in the Cheshire area (so these represent dual-permeability aquifers) but rises up to $\sim 10^{2}$ in the shallow depth St Bees Sandstone of the Eastern Irish Sea Basin (essentially a fracture flow aquifer; Brassington and Walthall 1985; Medici et al. 2016; Price et al. 1982).

Data reported in Fig. 8 suggest that, below shallow alteration zones $(<\sim 150 \mathrm{mBGL})$, fractures in siliciclastic continental deposits progressively close, which leads to dominance of matrix flow at depth $>\sim 700 \mathrm{mBGL}$. In fact, core-plug and well-test scales substantially coincide $\left(K_{\text {well-test }} / K_{\text {core-plug }}\right.$ $\sim 1.1-1.3$ ) at such depth in the Triassic fluvial deposits of the St Bees Sandstone of the eastern Irish Sea Basin and in the Stuttgart Formation of the North German Basin (Förster et al. 2006; Medici et al. 2018). Nevertheless, subhorizontal (0-15 $\left.{ }^{\circ}\right)$ bedding plane fractures up to $\sim 1 \mathrm{~km}$ depth contribute to enhance flow anisotropy favouring flow in directions parallel to the beds, leading to aquifer anisotropy that impedes rise of contaminants related to shale gas extraction at such elevated depths (Cai and Ofterdinger 2014; Wilson et al. 2017).

Figures 8 shows how, at depths $>1 \mathrm{~km}$ BGL, matrix flow dominates, because the ratio between core-plug- and well-testscale hydraulic conductivity approximates unity and well-testscale permeability closely approximates intergranular permeability, as illustrated by data from the Mae-Taeng Formation ( $2.8 \mathrm{~km}$ depth) in the Gulf of Thailand, the Ness Formation
( 2.9 km depth) of the North Sea, and the Nugget Sandstone Formation ( $\sim 3.9 \mathrm{~km}$ depth) in Wyoming, USA (Bennett and Clark, 1985; Zheng et al. 2000, 2003). Note that temperature and electrical fluid conductivity logs undertaken at depths $>\sim 700 \mathrm{mBGL}$ in the studied fluvio-aeolian sandstones (Figs. 8, 9) do not show spikes in correspondence of large bedding plane discontinuities (Förster et al. 2006; Medici et al. 2018; Zheng et al. 2000).

\section{Nature of alteration and matrix versus fracture flow in continental siliciclastic successions}

Alteration of bedding planes and vertical joints has been detected using optical televiewer logs in the Penrith Sandstone and the St Bees Sandstone aquifers of NW England; here, alteration was related to dissolution of calcite cement in correspondence of fractures and matrix pores adjacent to discontinuities (Price et al. 1982; Medici et al. 2016). Dissolution of carbonate cement enhances porosity at depths $<\sim 0.15 \mathrm{kmBGL}$ in the UK Triassic Sherwood Sandstone of the Cheshire and Worcester basins, i.e. intergranular flow is significant in the latter two sedimentary successions $\left(1.3 \leq K_{\text {well-test }} / K_{\text {core-plug }} \geq 4.0\right.$; Fig. 9). Here, isotopic, major and trace element geochemistry show how calcite and dolomite cements dissolve to produce bicarbonate, magnesium and calcium ions in the UK Sherwood Sandstone Group (Shand et al. 2007). 
Fig. 9 Ratio $\left(K_{\text {well-test }} / K_{\text {core-plug }}\right)$ between well-test-scale and coreplug-scale hydraulic conductivity vs. depth (vertical bars show well screen intervals)

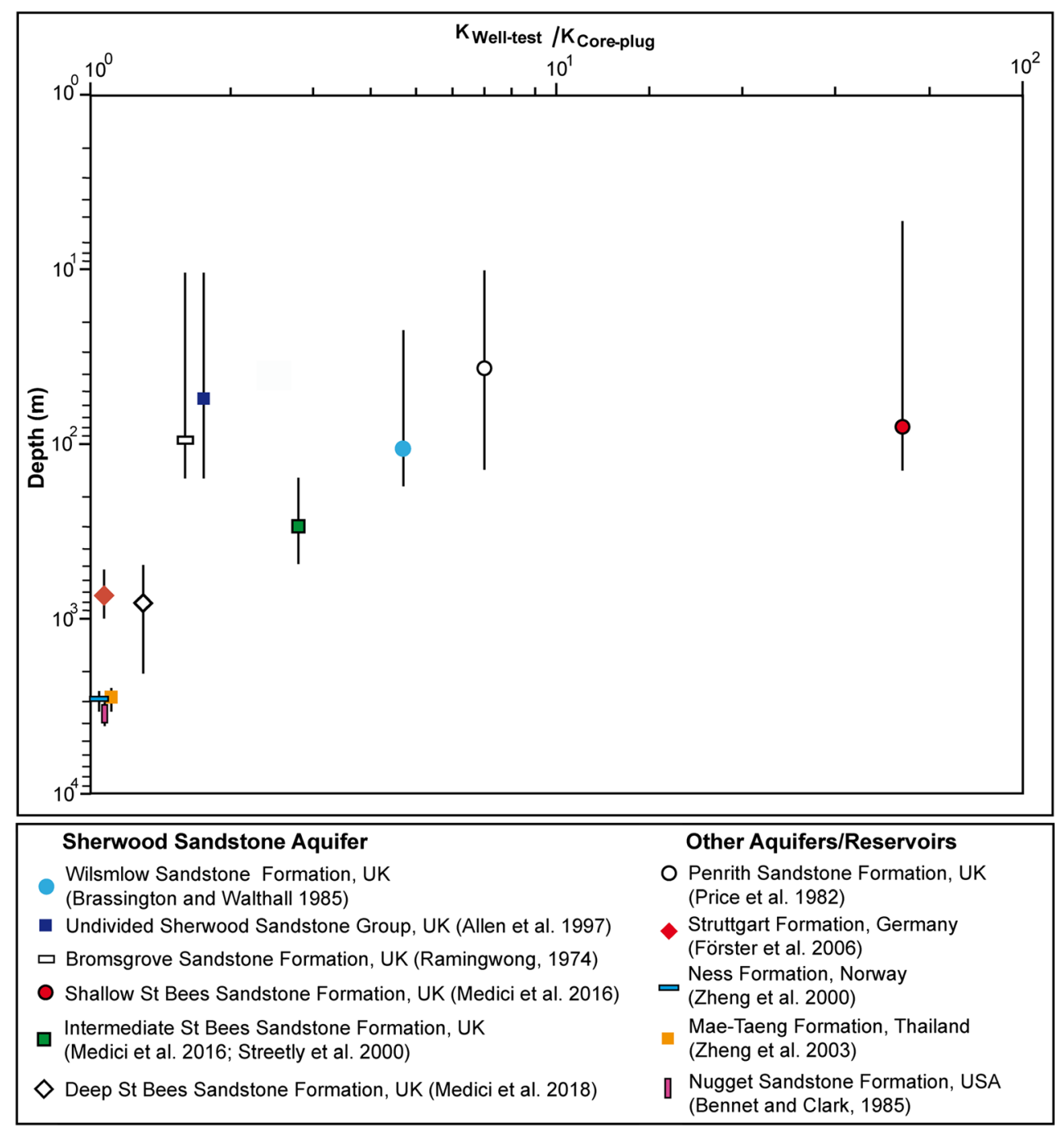

Dissolution of carbonate cement, which acts to enlarge pores and fractures, explains the high well-test-scale permeability observed in siliciclastic successions at shallow ( $\sim 0.15 \mathrm{~km}$ depth) depths (Figs. 8 and 9 ). Recharge and strong groundwater flow at such depths guarantee efficient groundwater refreshment in fractured aquifers. As a consequence of this, fresh groundwater dissolves calcite which is the soluble cement at shallow depths $(\sim 0-0.15 \mathrm{~km})$ (Kůrková et al. 2019; Worthington et al. 2016).

However, carbonate cement dissolution processes do not fully explain the relative importance of fracture vs. matrix flow in shallow sandstone aquifers, which seems to be largely determined by the mechanical properties of the sandstone such as the UCS (Table 1). Indeed, the Sherwood Sandstone aquifer of the eastern England Shelf and Worcester Basin, which are dominated by matrix flow, are mechanically weak and are not heavily fractured in outcropping faces and boreholes (Fig. 3a). Stratabound fractures are absent in the pebble beds units of the Worcester Basin and typically do not occur in the Triassic sandstone of the eastern England Shelf (Allen et al. 1998; Bouch et al. 2006).

However, fracture flow exceeds intergranular flow in the relatively highly mechanically resistant (see values of $\mathrm{UCS}_{\text {nat }}$ in Table 1) continental successions of the Sherwood Sandstone Group in the Cheshire and eastern Irish Sea basins and in the Permian Penrith Sandstone Formation (Brassington and Walthall 1985; Gellasch et al. 2013; Price et al. 1982; Swanson et al. 2006). Notably, the shallow St Bees Sandstone aquifer is characterized by a particularly elevated ratio between well-test- and core-scale hydraulic conductivity $\left(\sim 10^{2}\right)$, with respect to other mechanically resistant and fractured sandstone types (Fig. 9).

The highly mechanically resistant sandstone aquifers (including St Bees Sandstone aquifer of the eastern Irish Sea Basin) show several common characteristics. The St Bees Sandstone, the Wilsmlow and the Penrith Sandstone aquifers of NW England are all characterized by silica-carbonate cement (Table 1). Additionally, these aquifers are currently exposed to weathering in wet climatic conditions. Hence, they 
show a similar potential in terms of carbonate dissolution by groundwater flow (Burley 1984; Hoholick et al. 1984; Naylor et al. 1989; Strong et al. 1994; Shutes et al. 1997). Furthermore, the St Bees Sandstone aquifer has been exposed to weathering for significant time $(\sim 2.4 \mathrm{Myr})$ and is characterized by a similar stratabound fracturing network as the Wilsmlow and Penrith sandstone aquifers due to contemporaneous Cenozoic uplift in NW Europe (Carminati et al. 2009; Chadwick et al. 1994; Chadwick 1997).

The case of the St Bees Sandstone aquifer of the St BeesEgremont area remains somewhat unique with regard to its very high ratio of well-test hydraulic conductivity to coreplug-scale hydraulic conductivity (Fig. 9). This is because local conditions enhance alteration in correspondence of bedding and stratabound fractures. The St Bees Sandstone aquifer is located in a coastal setting, with tested boreholes located $\sim 5 \mathrm{~km}$ west of the edge of the Lake District topographic high (Black and Brightman 1996; Brassington and Walthall 1985). Thus, particularly rapid groundwater flow occurs, driven by the topographic slope towards the sea, which is indicated by measurements undertaken by the Westbay monitoring system in the Sellafield plain which shows hydraulic gradients ranging from 0.15 to 0.35 (Black and Brightman 1996).

\section{Conceptual model of the hydraulic property variation with depth in continental siliciclastic successions}

This review of the hydraulic properties of sandstone aquifers of fluvial and aeolian origin has resulted in the development of the conceptual model illustrated in Fig. 10. Such sandstone types are characterized by reduction of well-test-scale hydraulic conductivity due to the decrease of fracture alteration and closure processes at increasing depth. A key factor which controls the hydraulic properties of sandstone aquifers at relatively shallow depths $(<\sim 150 \mathrm{mBGL})$ is represented by their mechanical resistance. Weak $\left(\mathrm{UCS}_{\text {nat }}<20 \mathrm{MPa}\right)$ sandstone types (e.g., Bromgrove Sandstone Formation) which show a less developed fracturing network even at shallow depths, are characterized by a dominance of matrix flow. However, fracture flow exceeds matrix flow in sandstone aquifers which are characterized by high mechanical resistance (e.g., St Bees Sandstone and the Penrith Sandstone formations) due to development of pervasive fracturing networks. This hydraulic scenario can be extreme, as for the St Bees Sandstone aquifer (Medici et al. 2016), when local conditions strongly enhance groundwater alteration of fractures (Fig. 10, top left). Steep morphologies occurring in the proximity of horsts typically trigger greater groundwater flow and alteration (Black and Brightman 1996).

Below the shallow fracture alteration zones, well-test-scale hydraulic conductivity in siliciclastic successions tends towards the core-plug-derived values, although this happens at shallower depths for less mechanically resistant formations
(Fig. 10, middle row). However, at depths $>\sim 1 \mathrm{~km}$, all lithotypes investigated show essentially matrix-flow responses approaching the hydraulic behaviour of deep (1$4 \mathrm{~km}$ ) hydrocarbon reservoirs (Fig. 10, bottom row). Such deep siliciclastic aquifers are characterized by much higher effective flow porosity with respect to their shallow $(<\sim 0.15 \mathrm{~km})$ analogues. Thus, a smaller volume of rock is involved in flow in fracture flow systems, with consequent higher velocity of groundwater flow in shallow aquifers of fluvial and aeolian origin (Berkowitz 2002; Freeze 1975).

\section{Role of tectonic structures: normal faults in continental siliciclastic successions}

Deformation bands in association with normal faults are found in porous sandstone of continental origin throughout the world (Fossen et al. 2007; Torabi et al. 2013). Notably, a large amount of literature on such low-permeability tectonic structures focuses on the aeolian-dominated successions in the Paleo-Mesozoic Nubian Sandstone of Egypt (Du Bernard et al. 2002; Tueckmantel et al. 2010), the Permo-Triassic of the North Sea and Great Britain (Fisher and Knipe 2001; Beach et al. 1997; De Paola et al. 2005; Tueckmantel et al. 2012; Griffiths et al. 2018) and the Jurassic of northern America (Aydin 1978; Antonellini et al. 1994, 1995; Davis 1999). However, normal faults in the fluvial parts of the Triassic Sherwood Sandstone Group succession of UK represent enhanced fluid-flow pathways due to a higher occurrence of open fracture vs. deformation bands in fault zones (Knott 1994; Tellam and Barker 2006; Medici et al. 2016). The proportion of deformation bands vs. open fractures in porous sandstone depends on three factors which are the fault total throw, burial history and lithology (Fisher and Knipe 1998; Fisher et al. 2018; Mair et al. 2002). As a consequence, Fossen et al. (2007) compared architecture of faults which deform deposits of fluvial and aeolian origin of similar scale. These authors found that the density of deformation bands in the Jurassic aeolian deposits of Utah is $\sim 100$ higher than the Triassic fluvial deposits of the North Sea in faults with total throw ranging from 20 to $50 \mathrm{~m}$ (Fossen et al. 2007). Here, faulted blocks show no geochemical evidence of compartmentalization in these fluvial hydrocarbon reservoirs (Hesthammer and Fossen 2001; McKie and Audretsch 2005). By contrast, geochemistry shows how normal faults in the aeolian deposits of the UK Sherwood Sandstone Group strongly compartmentalize the aquifer due to development of swarms of deformation bands (Fig. 6; Griffiths et al. 2018; Mohamed and Worden 2006; Seymour et al. 2006).

Low-porosity bands also effectively reduce hydraulic conductivity in well tests in the Jurassic aeolian reservoirs of the Nugget Sandstone Formation in Wyoming, Idaho and Utah, USA (Lewis and Couples 1993; Olsson et al. 2004). In fact, the aeolian equivalents of the Nugget Sandstone in the 
Fig. 10 Conceptual model of flow to wells in siliciclastic sandstones at increasing depth (unfaulted areas). $K$ is hydraulic conductivity

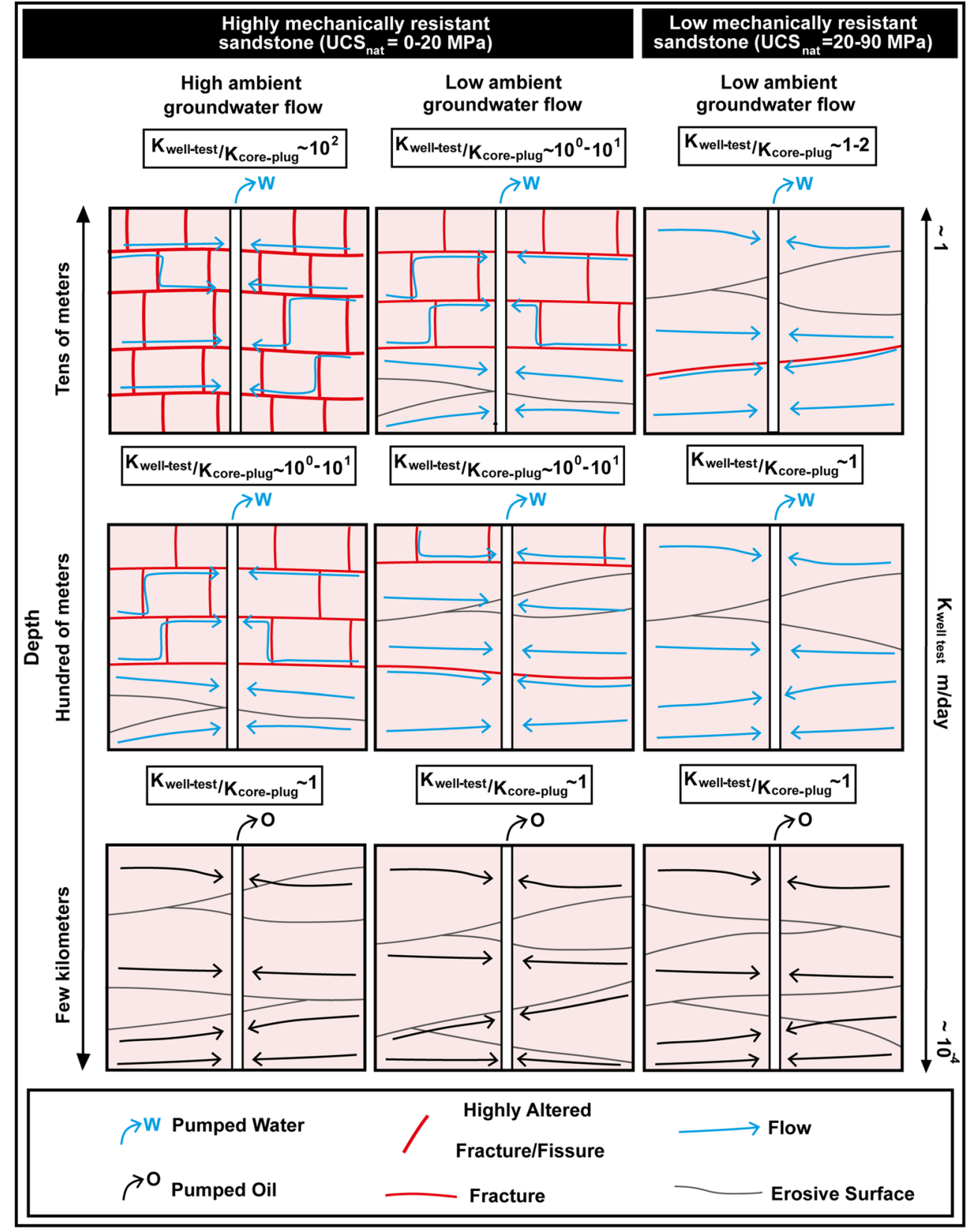

Jurassic of Colorado and Utah (the Navajo Sandstone) and Arizona (the Aztec Sandstone), are also characterized by a systematic dominance of deformation bands in fault zones (Antonellini and Aydin 1995; Davis 1999; Fossen et al. 2007; Sternlof et al. 2004). Reduction in well-test-scale permeability in aeolian reservoirs contrasts with the general hydraulic behaviour of faults in sedimentary basins which, despite the presence of a range of flow barriers (e.g., deformation bands, mineralized veins, normal drags and fault smears), typically represent favourable flow pathways where wells penetrate the main fault plane (Ball et al. 2010; Bense et al. 2013; Caine et al. 1996).
The contrasting behaviour of deposits of fluvial and aeolian origin is illustrated in Fig. 7 for the UK Triassic Sherwood Sandstone Group. Global applicability of this scenario to the fluvial and aeolian successions now represent an achievable challenge. Comparison of the hydro-structural elements of faults in different basins which are related to different rift settings is not straightforward due to their different burial history (Antonellini et al. 1994; Fossen et al. 2007). Despite this, generalization of the proposed conceptual hydraulic model of faults in fluvio-aeolian sequences is possible via analogue and numerical models of deformation. Indeed, to date such models for development of deformation bands do not consider 
differences on relative proportion of quartz, feldspar and clays in sandstone (De Paola et al. 2005; Olsson et al. 2004; Fossen et al. 2007; Klimczak et al. 2011; Tindall and Eckert 2015).

\section{Conclusions}

This article provides valuable insights for management of deep $(\sim 0.15-2.0 \mathrm{~km})$ siliciclastic fluvio-aeolian aquifers which are the object of renewed attention due to the growing interest in geothermal energy and protection from escape of contaminants from deep hydraulic fracturing of shale gas reservoirs, and in connection with deep nuclear waste repositories. Normal faults in fluvial siliciclastic deposits represent flow heterogeneities of tectonic origin which typically act as favourable flow pathways potentially enhancing production from geothermal wells which target these faults planes, but also increasing the potential for escape of contaminants from deep shale gas reservoirs and nuclear waste repository facilities. However, normal faults in aeolian deposits are commonly associated with high-density networks of deformation bands; as such, these faults act to reduce well-test-scale hydraulic conductivity, even in cases where they are intercepted by the producing well.

Both well-test-scale hydraulic conductivity and the ratio between well-test- and core-plug-scale hydraulic conductivity decreases with depth in both fluvial and aeolian siliciclastic sedimentary successions. Changes in this ratio arise from a much larger reduction in fracture permeability compared to matrix permeability, with increasing depth. This is due to fracture alteration (driven by calcite cement dissolution) being restricted to the zone of meteoric groundwater circulation in approximately the upper hundred metres, and fracture closure by lithostatic pressure at greater depths.

The ratio between well-test- and core-plug-scale hydraulic conductivity is typically relatively high $(\sim 4)$ at shallow depths $(<\sim 150 \mathrm{mBGL})$ in relatively high mechanically resistant $\left(\mathrm{UCS}_{\text {nat }}>\sim 20 \mathrm{MPa}\right)$ sandstones due to favourable conditions for fracture development. The ratio rises to $\sim 100$ in the shallow St Bees Sandstone aquifer, in a coastal setting close to the bounding basin faults, due to particularly vigorous groundwater flow related to the presence of an adjacent morphostructural high (the Lake District Massif). The difference between core-plug- and well-test-scale hydraulic conductivity decreases in mechanically resistant sandstones at greater depths, approaching unity at $\sim 1 \mathrm{~km}$ depth. Thus, above this threshold depth, bedding plane fractures are capable of flow. However, at depths $>\sim 1 \mathrm{~km}$, siliciclastic successions of continental origin are dominated by intergranular flow, and hence are approaching the hydraulic behaviour of hydrocarbon reservoirs at even greater depths (up to $\sim 4 \mathrm{~km}$ ). Mechanically weak terrestrial siliciclastic aquifers are dominated by intergranular flow even at relatively shallow depths $(<\sim 150$ $\mathrm{mBGL}$ ) because they are less prone to fracture development.

Results from this review find practical applicability in management of deep aquifers. Indeed, faults in fluvial deposits represent an optimum target, at least in comparison to those displacing aeolian successions, for enhancing recovery of fluids in geothermal reservoirs. Despite this, flowing bedding plane fractures can partially take over from this conduit behaviour in fluvial deposits. Bedding planes may favour fluid flow parallel to the beds discouraging the rise of contaminants from nuclear waste repositories and hydrofracturing of shale gas reservoirs near faults. The contribution of mechanical discontinuities to flow in fluvial-aeolian successions decreases with depth to a level where intergranular flow becomes dominant. In matrix flow aquifers, the effective flowing (kinematic) porosity, which represents a key parameter for modelling of solute contaminant transport, is larger than that in fracture flow systems. Thus, with increasing depth in fluvial-aeolian successions, there tends to be a decrease in the migration velocities of contaminants. In this article, the hydraulic properties of fluvio-aeolian sedimentary successions have been reviewed to develop better-informed conceptual models over a wide depth interval $(\sim 0-4 \mathrm{~km})$, which is of particular interest across multiple branches of the energy industry sector.

Acknowledgements The results of this study benefitted from discussions with Antoni Milodowski (British Geological Survey), Luca Colombera (University of Leeds, UK), and Philippe Ruelland and Gérard Massonnat (Total E\&P) regarding the flow behaviour of sandstones. Additionally, Noelle Odling (formerly of University of Leeds), Quentin Fisher (University of Leeds), Anita Torabi (Centre for Integrated Petroleum Research, Norway) and Marco Antonellini (University of Bologna, Italy) gave useful insights on development of stratabound joints and deformation bands in fluvial-aeolian successions. Finally, we are grateful for the constructive comments of editor Martin Appold, associate editor Andrew Frampton, and reviewers Victor Bense and Guanghui Yuan.

Funding information The authors thank Total E\&P UK Limited for funding this research project.

Open Access This article is distributed under the terms of the Creative Commons Attribution 4.0 International License (http:// creativecommons.org/licenses/by/4.0/), which permits unrestricted use, distribution, and reproduction in any medium, provided you give appropriate credit to the original author(s) and the source, provide a link to the Creative Commons license, and indicate if changes were made.

\section{References}

Abesser C, Lewis M (2015) A semi-quantitative technique for mapping potential aquifer productivity on the national scale: example of England and Wales (UK). Hydrogeol J 23(8):1677-1694. https:// doi.org/10.1007/s10040-015-1295-5 
Aldinucci M, Gandin A, Sandrelli F (2008) The Mesozoic continental rifting in the Mediterranean area: insights from the Verrucano tectofacies of southern Tuscany (northern Apennines, Italy). Int J Earth Sci 97:1247-1269. https://doi.org/10.1007/s00531-0070208-9

Al-Hinai S, Fisher QJ, Al-Busafi B, Guise P, Grattoni CA (2008) Laboratory measurements of the relative permeability of cataclastic fault rocks: an important consideration for production simulation modelling. Mar Pet Geol 25(6):473-485. https://doi.org/10.1016/j. marpetgeo.2007.07.005

Allen DJ, Brewerton LM, Coleby BR, Gibbs MA, Lewis AM, MacDonald SJ, Wagstaff AT, Williams LJ (1997) The physical properties of major aquifers in England and Wales. Technical report WD/97/34, British Geological Survey, Nottingham, UK

Allen DJ, Bloomfield JP, Gibbs BR, Wagstaff SJ (1998) Fracturing and the hydrogeology of the Permo-Triassic sandstones in England and Wales. Technical report WD/98/001, British Geological Survey, Nottingham, UK

Allen PA, Verlander JE, Burgess PM, Audet DM (2000) Jurassic giant erg deposits, flexure of the United States continental interior, and timing of the onset of cordilleran shortening. Geology 28:159-162. https:// doi.org/10.1130/0091-7613

Ambrose K, Hough E, Smith NJP, Warrington G (2014) Lithostratigraphy of the Sherwood Sandstone Group of England, Wales and southwest Scotland. Research report RR/14/01, British Geological Survey, Nottingham, UK

Antonellini M, Aydin A (1995) Effect of faulting on fluid flow in porous sandstones: geometry and spatial distribution. AAPG Bull 79:642670

Antonellini M, Aydin AA, Pollard DD (1994) Microstructure of deformation bands in porous sandstones at Arches National Park, Utah. J Struct Geol 16:941-959. https://doi.org/10.1016/0191-8141(94) 90077-9

Aronson J, Burtner RL (1983) K/Ar dating of Illitic clays in Jurassic nugget sandstone and timing of petroleum migration in Wyoming Overthrust Belt: abstract. AAPG Bull 67:414

Aydin A (1978) Small faults formed as deformation bands in sandstone. In: Byerlee JD, Wyss M (eds) Rock friction and earthquake prediction. Contributions to Current Research in Geophysics (CCRG), vol 6. Birkhauaser, Basel, Switzerland

Aydin A, Nur A (1982) Evolution of pull-apart basins and their scale independence. Tectonics 1(1):91-105. https://doi.org/10.1029/ TC001i001p00091

Ball LB, Ge S, Caine JS, Revil A, Jardani A (2010) Constraining faultzone hydrogeology through integrated hydrological and geoelectrical analysis. Hydrogeol J 18(5):1057-1067. https://doi. org/10.1007/s10040-010-0587-z

Bath AH, Milodowski AE, Spiro B (1987) Diagenesis of carbonate cements in Permo-Triassic sandstones in the Wessex and East Yorkshire-Lincolnshire basins, UK: a stable isotope study. Geol Soc Spec Publ 36(1):173-190. https://doi.org/10.1144/GSL.SP. 1987.036.01.14

Beach A, Brown JL, Welbon AI, McCallum JE, Brockbank P, Knott S (1997) Characteristics of fault zones in sandstones from NW England: application to fault transmissibility. Geol Soc Spec Publ 124(1):315-324. https://doi.org/10.1144/GSL.SP.1997.124.01.19

Bennett CO, Clark TJ (1985) Design and analysis of a nitrogen step-rate test, Anschutz Ranch East Nitrogen Injection Project. In: SPE annual technical conference and exhibition. Soc Petrol Eng. https://doi. org/10.2118/14456-MS

Bense VF, Gleeson T, Loveless SE, Bour O, Scibek J (2013) Fault zone hydrogeology. Earth Sci Rev 127:171-192. https://doi.org/10.1016/ j.earscirev.2013.09.008

Bense VF, Shipton ZK, Kremer Y, Kampman N (2016) Fault zone hydrogeology: introduction to the special issue. Geofluids 16(4):655-657
Berkowitz B (2002) Characterizing flow and transport in fractured geological media: a review. Adv Water Resour 25(8-12):861-884. https://doi.org/10.1016/S0309-1708(02)00042-8

Black JH, Brightman MA (1996) Conceptual model of the hydrogeology of Sellafield. Q J Eng Geol Hydrogeol 29:83-93. https://doi.org/10. 1144/GSL.QJEGH.1996.029.S1.06

Bloomfield JP, Moreau MF, Newell AJ (2006) Characterization of permeability distribution in six lithofacies from the Helsby and Wilmslow Sandstone formations of the Cheshire Basin, UK. Geol Soc Spec Publ 263:83-101. https://doi.org/10.1144/GSL.SP.2006. 263.01.04

Bosellini A (1989) Dynamics of Tethyan carbonate platforms. Soc Econ Paleontol Minera Spec Publ 44:3-14

Bouch JE, Hough E, Kemp SJ, McKervey JA, Williams GM, Greswell RB (2006) Sedimentary and diagenetic environments of the Wildmoor Sandstone formation (UK): implications for groundwater and contaminant transport, and sand production. Geol Soc Spec Publ 263:129-153. https://doi.org/10.1144/GSL.SP.2006.263.01.07

Brassington FC, Walthall S (1985) Field techniques using borehole packers in hydrogeological investigations. Q J Eng Geol Hydrogeol 18:181-193. https://doi.org/10.1144/GSL.QJEG.1985. 018.02 .07

Brookfield ME (2004) The enigma of fine-grained alluvial basin fills: the Permo-Triassic (Cumbrian coastal and Sherwood sandstone groups) of the Solway Basin, NW England and SW Scotland. Int J Earth Sci 93:282-296. https://doi.org/10.1007/s00531-004-0381-z

Brookfield ME (2008) Palaeoenvironments and palaeotectonics of the arid to hyperarid intracontinental latest Permian-late Triassic Solway basin (UK). Sediment Geol 210:27-47. https://doi.org/10. 1016/j.sedgeo.2008.06.003

Burley SD (1984) Patterns of diagenesis in the Sherwood Sandstone Group (Triassic), United Kingdom. Clay Miner 19:403-440

Cai Z, Ofterdinger U (2014) Numerical assessment of potential impacts of hydraulically fractured Bowland shale on overlying aquifers. Water Resour Res 50(7):6236-6259. https://doi.org/10.1002/ 2013WR014943

Caine JS, Evans JP, Forster CB (1996) Fault zone architecture and permeability structure. Geology 24(11):1025-1028. https://doi.org/10. 1130/0091-7613

Carminati E, Cuffaro M, Doglioni C (2009) Cenozoic uplift of Europe. Tectonics 28:TC4016. https://doi.org/10.1029/2009TC002472

Chadwick RA (1997) Fault analysis of the Cheshire Basin, NW England. Geol Soc Spec Publ 124:297-313. https://doi.org/10.1144/GSL.SP. 1997.124.01.18

Chadwick RA, Evans DJ (1995) The timing and direction of PermoTriassic extension in southern Britain. In: Permian and Triassic rifting in Northwest Europe. Geol Soc Spec Publ 91:161-192. https://doi.org/10.1144/GSL.SP.1995.091.01.09

Chadwick RA, Kirby GA, Baily HE (1994) The post-Triassic structural evolution of North-West England and adjacent parts of the East Irish Sea. Proceed York Geol Soc 50:91-102. https://doi.org/10.1144/ pygs.50.1.91

Charalambous AN, Packman M, Burnet BR (2012) Sand pumping and well design in consolidated and semi-consolidated sandstone aquifers. Q J Eng Geol Hydrogeol 45:183-196. https://doi.org/10.1144/ 1470-9236/11-016

Chiarabba C, Amato A, Fiordelisi A (1995) Upper crustal tomographic images of the Amiata-Vulsini geothermal region, central Italy. J Geophys Res Solid Earth 100:4053-4066. https://doi.org/10.1029/ 94JB02870

Colombera L, Mountney NP (2019) The lithofacies organization of fluvial channel deposits: a meta-analysis of modern rivers. Sediment Geol 383:16-40. https://doi.org/10.1016/j.sedgeo.2019.01.011

Colombera L, Mountney NP, McCaffrey WD (2012) A relational database for the digitization of fluvial architecture: concepts and 
example applications. Pet Geosci 18:129-140. https://oi.org/10. 1144/1354-079311-021

Colombera L, Mountney NP, Medici G, West LJ (2019) The geometry of fluvial channel bodies: empirical characterization and implications for object-based models of the subsurface. AAPG Bull 103(4):905929

Condon SM (1997) Geology of the Pennsylvanian and Permian cutler group and Permian Kaibab limestone in the Paradox Basin, southeastern Utah and southwestern Colorado. US Geol Surv Bull 2000

Corbett PWM, Hamidreza H, Hemant G (2012) Layered fluvial reservoirs with internal fluid cross flow: a well-connected family of well test pressure transient responses. Pet Geosci 18:219-229. https://doi.org/ 10.1144/1354-079311-008

Davis GH (1999) Structural geology of the Colorado Plateau region of southern Utah, with special emphasis on deformation bands. Geol Soc Am Spec Pap 342

Daw GP, Howell FT, Woodhead GA (1974) The effect of applied stress upon the permeability of some Permian and Triassic sandstones of northern England. Int J Rock Mech Min Sci Geomech Abstr 13: $537-542$

De Paola N, Holdsworth RE, McCaffrey KJW (2005) The influence of lithology and pre-existing structures on reservoir-scale faulting patterns in transtensional rift zones. J Geol Soc 162(3):471-480. https:// doi.org/10.1144/0016-764904-043

Dreyer T, Corregidor J, Arbues P, Cai P (1999) Architecture of tectonically influenced Sobrarbe deltaic complex in the Ainsa Basin, northern Spain. Sediment Geol 127(3-4):127-169. https://doi.org/10. 1016/S0037-0738(99)00056-1

Du Bernard X, Labaume P, Darcel C, Davy P, Bour O (2002) Cataclastic slip band distribution in normal fault damage zones, Nubian sandstones, Suez Rift. J Geophys Res Solid Earth 107(B7). https://doi. org/10.1029/2001JB000493

Evans DJ, Rees JG, Holloway S (1993) The Permian to Jurassic stratigraphy and structural evolution of the Cheshire Basin. J Geol Soc 150:857-870. https://doi.org/10.1144/gsjgs.150.5.0857

Ferguson G (2012) Characterizing uncertainty in groundwater-source heating and cooling projects in Manitoba, Canada. Energy 37(1): 201-206. https://doi.org/10.1016/j.energy.2011.11.045

Ferguson G (2015) Deep injection of waste water in the Western Canada Sedimentary Basin. Groundwater 53(2):187-194. https://doi.org/10. 1111/gwat.12198

Fisher QJ, Knipe R (1998) Fault sealing processes in siliciclastic sediments. Geol Soc Spec Publ 147(1):117-134. https://doi.org/10. 1144/GSL.SP.1998.147.01.08

Fisher QJ, Casey M, Harris SD, Knipe RJ (2003) Fluid-flow properties of faults in sandstone: the importance of temperature history. Geology 31(11):965-968. https://doi.org/10.1130/G19823.1

Fisher QJ, Haneef J, Grattoni CA, Allshorn S, Lorinczi P (2018) Permeability of fault rocks in siliciclastic reservoirs: recent advances. Mar Pet Geol 91:29-42. https://doi.org/10.1016/j. marpetgeo.2017.12.019

Flewelling SA, Sharma M (2014) Constraints on upward migration of hydraulic fracturing fluid and brine. Groundwater 52:9-19. https:// doi.org/10.1111/gwat.12095

Ford M, Tellam JH (1994) Source, type and extent of inorganic contamination within the Birmingham urban aquifer system, UK. J Hydrol 156(1-4):101-135. https://doi.org/10.1016/0022-1694(94)90074-4

Förster A, Norden B, Zinck-Jørgensen K, Frykman P, Kulenkampff J, Spangenberg E, Erzinger J, Zimmer M, Kopp J, Borm G, Juhlin C (2006) Baseline characterization of the CO2SINK geological storage site at Ketzin, Germany. Environ Geosci 13(3):145-161

Fossen H, Schultz RA, Shipton ZK, Mair K (2007) Deformation bands in sandstone: a review. J Geol Soc 164:755-769. https://doi.org/10. 1144/0016-76492006-036

Freeze RA (1975) A stochastic-conceptual analysis of one-dimensional groundwater flow in nonuniform homogeneous media. Water
Resour Res 11(5):725-741. https://doi.org/10.1029/ WR011i005p00725

Gellasch CA, Bradbury KR, Hart DJ, Bahr JM (2013) Characterization of fracture connectivity in a siliciclastic bedrock aquifer near a public supply well (Wisconsin, USA). Hydrogeology Journal 21(2):383399

GeoMappApp (2019) Free software v3.6.10. www.geomapapp.org. Accessed September 2019

Gibson RG (1998) Physical character and fluid-flow properties of sandstone-derived fault zones. Geol Soc Spec Publ 127:83-97. https://doi.org/10.1144/GSL.SP.1998.127.01.07

Gillespie PA, Walsh JJ, Watterson J, Bonson CG, Manzocchi T (2001) Scaling relationships of joint and vein arrays from the Burren, Co. Clare, Ireland. J Struct Geol 23:183-201. https://doi.org/10.1016/ S0191-8141(00)00090-0

Giordano G, Pinton A, Cianfarra P, Baez W, Chiodi A, Viramonte J, Norini G, Groppelli G (2013) Structural control on geothermal circulation in the Cerro Tuzgle-Tocomar geothermal volcanic area (Puna plateau, Argentina). Journal of Volcanology and Geothermal Research 249:77-94

Griffiths J, Faulkener DR, Alexander PE, Worden RH (2016) Deformation band development as a function of intrinsic host-rock properties in Triassic Sherwood Sandstone. Geol Soc Spec Publ 435:1-11. https://doi.org/10.1144/SP435.11

Griffiths J, Faulkner DR, Edwards AP, Worden RH, 2018. Deformation band development as a function of intrinsic host-rock properties in Triassic Sherwood Sandstone. Geological Society, London, Special Publications 435(1):161-176

Gutmanis JC, Lanyon GW, Wynn TJ, Watson CR (1998) Fluid flow in faults: a study of fault hydrogeology in Triassic sandstone and Ordovician volcaniclastic rocks at Sellafield, North-West England. Proceed York Geol Soc 52(2):159-175. https://doi.org/10.1144/ pygs.52.2.159

Hawkins AB, McConnell BJ (1992) Sensitivity of sandstone strength and deformability to changes in moisture content. Q J Eng Geol Hydrogeol 25:115-130. https://doi.org/10.1144/GSL.QJEG.1992. 025.02 .05

Heinrichs G, Udluft P (1999) Natural arsenic in Triassic rocks: a source of drinking-water contamination in Bavaria, Germany. Hydrogeol J $7(5): 468-476$

Hesthammer J, Fossen H (2001) Structural core analysis from the Gullfaks area, northern North Sea. Mar Pet Geol 18(3):411-439. https://doi.org/10.1016/S0264-8172(00)00068-4

Hillis RR, Holford SP, Green PF, Dore AG, Gatliff RW, Stoker MS, Thomson K, Turner JP, Underhill JR, Williams GA (2008) Cenozoic exhumation of the southern British Isles. Geology 36: 371-374. https://doi.org/10.1130/G24699

Hitchmough AM, Riley MS, Herbert AW, Tellam JH (2007) Estimating the hydraulic properties of the fracture network in a sandstone aquifer. J Contam Hydrol 93:38-57. https://doi.org/10.1016/j.jconhyd. 2007.01.012

Hoholick JD, Metarko T, Potter PE (1984) Regional variations of porosity and cement: St. Peter and Mount Simon sandstones in Illinois Basin. AAPG Bull 68:753-764

Holliday HD, Jones NS, McMillan AA (2008) Lithostratigraphical subdivision of the Sherwood Sandstone Group (Triassic) of the northeastern part of the Carlisle Basin, Cumbria and Dumfries and Galloway, UK. Scott J Geol 44:97-110. https://doi.org/10.1144/ sjg44020097

Holloway S, Milodowski AE, Strong GE, Warrington G (1989) The Sherwood Sandstone Group (Triassic) of the Wessex Basin, southern England. Proc Geol Assoc 100(3):383-394. https://doi.org/10. 1016/S0016-7878(89)80056-2

Hounslow MW, McIntosh G, Richard RA, Edwards A, Deryck JCL, Karloukovski V (2017) End of the Kiaman Superchron in the Permian of SW England: magnetostratigraphy of the Aylesbeare 
mudstone and Exeter groups. J Geol Soc 174:56-74. https://doi.org/ 10.1144/jgs2015-141

Ixer RA, Turner P, Waugh P (1979) Authigenic iron and titanium oxides in Triassic red beds:(St. Bees Sandstone), Cumbria, northern England. Geol J 14(2):179-192. https://doi.org/10.1002/gj. 3350140214

James WC, Wilmar GC, Davidson BG (1986) Role of quartz type and grain size in silica diagenesis, nugget sandstone, south-central Wyoming. J Sedim Resear 56:657-662. https://doi.org/10.1306/ 212F8A03-2B24-11D7-8648000102C1865D

Jones GL, Somerville ID, Strogen P (1988) The lower carboniferous (Dinantian) of the Swords area: sedimentation and tectonics in the Dublin Basin, Ireland. Geol J 23:221-248. https://doi.org/10.1002/ gj.3350230304

Kattenhorn SA, Pollard DD (2001) Integrating 3-D seismic data, field analogs, and mechanical models in the analysis of segmented normal faults in the Wytch Farm Oil Field, southern England, United Kingdom. AAPG Bull 85:1183-1210

Klimczak C, Soliva R, Schultz RA, Chéry J (2011) Sequential growth of deformation bands in a multilayer sequence. J Geophys Res Solid Earth 116(B9). https://doi.org/10.1029/2011JB008365

Knott SD (1994) Fault zone thickness versus displacement in the PermoTriassic sandstones of NW England. J Geol Soc 151:17-25. https:// doi.org/10.1144/gsigs.151.1.0017

Kortas L, Younger PL (2013) Fracture patterns in the Permian Magnesian limestone aquifer, Co. Durham, UK. Proceed York Geol Soc 59(3): 161-171. https://doi.org/10.1144/pygs2013-322

Kůrková I, Bruthans J, Balák F, Slavík M, Schweigstillová J, Bruthansová J, Mikuš P, Vojtíšek J, Grundloch J (2019) Factors controlling evolution of karst conduits in sandy limestone and calcareous sandstone (Turnov area, Czech Republic). J Hydrol. https:// doi.org/10.1016/j.jhydrol.2019.05.013

Lemieux JM, Therrien R, Kirkwood D (2006) Small scale study of groundwater flow in a fractured carbonate-rock aquifer at the StEustache Quarry, Québec, Canada. Hydrogeol J 14(4):603. https:// doi.org/10.1007/s10040-005-0457-2

Lemieux JM, Kirkwood D, Therrien R (2009) Fracture network analysis of the St-Eustache Quarry, Quebec, Canada, for groundwater resources management. Can Geotech J 46(7):828-841. https://doi. org/10.1139/T09-022

Lewis H, Couples GD (1993) Production evidence for geological heterogeneities in the Anschutz Ranch East Field, western USA. Geol Soc Spec Publ 321:321-338. https://doi.org/10.1144/GSL.SP.1993.073. 01.19

Lindquist SJ (1988) Practical characterization of eolian reservoirs for development: nugget sandstone, Utah-Wyoming thrust belt. Sediment Geol 56:315-339. https://doi.org/10.1016/00370738(88)90059-0

Loveless SE, Pluymaekers M, Lagrou D, De Boever E, Doornenbal H, Laenen B (2014) Mapping the geothermal potential of fault zones in the Belgium-Netherlands border region. Energy Procedia 59:351358

Loveless SE, Bloomfield JP, Robert SW, Alwyn JH, Davey IR, Lewis MA (2018) Characterising the vertical separation of shale-gas source rocks and aquifers across England and Wales (UK). Hydrogeol J 26(6):1975-1987. https://doi.org/10.1007/s10040$018-1737-\mathrm{y})$

Mair K, Elphick S, Main I (2002) Influence of confining pressure on the mechanical and structural evolution of laboratory deformation bands. Geophys Res Lett 29(10):49-41. https://doi.org/10.1029/ 2001GL013964

McKie T, Audretsch P (2005) Depositional and structural controls on Triassic reservoir performance in the Heron Cluster, ETAP, Central North Sea. In: Petroleum geology: North-West Europe and global perspectives. In: Doré AG, Vining BA (eds) Proceedings of the 6th Petroleum Geology Conference, Geological Society of London.
Petroleum Geology Conference Series vol 6, pp 285-297. https:// doi.org/10.1144/0060285z

McKie T, Williams B (2009) Triassic palaeogeography and fluvial dispersal across the northwest European basins. Geol J 44:711-741. https://doi.org/10.1002/gj.1201

McKie T, Shannon PM (2011) Comment on "The Permian-Triassic transition and the onset of Mesozoic sedimentation at the northwestern peri-Tethyan domain scale: palaeogeographic maps and geodynamic implications". Palaeogeogr Palaeoclimatol Palaeoecol 311:136 143. https://doi.org/10.1016/j.palaeo.2011.07.016

McKie T, Jolley SJ, Kristensen MB (2010) Stratigraphic and structural compartmentalization of dryland fluvial reservoirs: Triassic Heron Cluster, Central North Sea. Geol Soc Spec Publ 347:165-198. https://doi.org/10.1144/SP347.11

Meadows NS (2006) The correlation and sequence architecture of the Ormskirk Sandstone Formation in the Triassic Sherwood Sandstone Group of the East Irish Sea Basin, NW England. Geol J 41:93-112. https://doi.org/10.1002/gj.1034

Medici G, West LJ, Odling NE, Mountney NP (2014) Inferred fluid flow behaviour in a fractured red-bed aquifer: St Bees Sandstone Formation. 42nd IAH Congress: AQUA 2015, Rome, 13-18 Sep 2015, pp 66-67

Medici G, Boulesteix K, Mountney NP, West LJ, Odling NE (2015) Palaeoenvironment of braided fluvial systems in different tectonic realms of the Triassic Sherwood Sandstone Group, UK. Sediment Geol 329:188-210. https://doi.org/10.1016/j.sedgeo.2015.09.012

Medici G, West LJ, Mountney NP (2016) Characterizing flow pathways in a sandstone aquifer: tectonic vs sedimentary heterogeneities. J Contam Hydrol 194:36-58. https://doi.org/10.1016/j.jconhyd. 2016.09.008

Medici G, West LJ, Mountney NP (2018) Characterization of a sandstone fluvial aquifer-type at a variety of depths and scales: the Triassic St Bees Sandstone Formation, Cumbria. Hydrogeol J 26:565-591. https://doi.org/10.1007/s10040-017-1676-z

Medici G, West LJ, Banwart SA (2019a) Groundwater flow velocities in a fractured carbonate aquifer-type: implication for contaminant transport. J Contam Hydrol 222:1-16

Medici G, West LJ, Mountney NP (2019b) Sedimentary flow heterogeneities in the Triassic UK Sherwood Sandstone Group: insights for hydrocarbon exploration. Geol J. https://doi.org/10.1002/gj.3233

Miall AD (1996) The geology of fluvial deposits: sedimentary facies, basin analysis, and petroleum geology. Springer, Heidelberg, Germany

Mohamed EA, Worden RH (2006) Groundwater compartmentalisation: a water table height and geochemical analysis of the structural controls on the subdivision of a major aquifer, the Sherwood Sandstone, Merseyside, UK. Hydrol Earth Syst Sci 10:49-64

Morris BL, Darling WG, Cronin AA, Rueedi J, Whitehead EJ, Gooddy DC (2006) Assessing the impact of modern recharge on a sandstone aquifer beneath a suburb of Doncaster, UK. Hydrogeol J 14(6):979997. https://doi.org/10.1007/s10040-006-0028-1

Mountney NP, Thompson DB (2002) Stratigraphic evolution and preservation of aeolian dune and damp/wet interdune strata: an example from the Triassic Helsby sandstone formation, Cheshire Basin, UK. Sedimentology 49:805-833. https://doi.org/10.1046/j.1365-3091. 2002.00472.x

Naylor H, Turner P, Vaughan DJ, Boyce AJ, Fallick AE (1989) Genetic studies of red bed mineralization in the Triassic of the Cheshire Basin, Northwest England. J Geol Soc 146:685-699. https://doi. org/10.1144/gsjgs.146.4.0685

Newell AJ (2018) Rifts, rivers and climate recovery: a new model for the Triassic of England. Proc Geol Assoc 129(3):352-371. https://doi. org/10.1016/j.pgeola.2017.04.001

Nguyen BT, Jones SJ, Goulty NR, Middleton AJ, Grant N, Ferguson A, Bowen L (2013) The role of fluid pressure and diagenetic cements for porosity prelservation in Triassic fluvial reservoirs of the Central 
Graben, North Sea. AAPG Bull 97:1273-1302. https://doi.org/10. $1306 / 01151311163$

Nirex (1992a) Liquid permeability: gas permeability correlation for Permo-Trias samples from Sellafield boreholes Nos. 235 and 7. Nirex report 226, British Geological Survey, Nottingham, UK

Nirex (1992b) The geology and hydrogeology of Sellafield. Nirex report 263, British Geological Survey, Nottingham, UK

Nirex (1992c) Permeability and porosity results for samples from the Permo-Trias Carboniferous and Borrowdale Volcanic Group of Sellafield borehole 10. Nirex report 226, British Geological Survey, Nottingham, UK

Nirex (1993a) The geology and hydrogeology of the Sellafield area: interim assessment. Nirex report 524, British Geological Survey, Nottingham, UK

Nirex (1993b) Permeability and porosity results for samples from The Permo-Trias and Borrowdale Volcanic Group of Sellafield borehole RCF3 and the Permo-Trias of Sellafield borehole RCM2. Nirex report 806, British Geological Survey, Nottingham, UK

Nirex (1996a) Geological core logs $500 \mathrm{mbRT}$ to $1000 \mathrm{mbRT}$. Nirex report 107, British Geological Survey, Nottingham, UK

Nirex (1996b) Geological Core logs 500 mbRT to 1000 mbRT. Nirex report 108, British Geological Survey, Nottingham, UK

Nirex (1997) Sellafield geological and hydrogeological investigations: sedimentology and sedimentary architecture of the St Bees Sandstone Formation in West Cumbria. Nirex report SA/97/023, British Geological Survey, Nottingham, UK

Odling NE, Gillespie P, Bourgine B, Castaing C, Chiles JP, Christensen NP, Fillion E, Genter A, Olsen C, Thrane L, Trice R (1999) Variations in fracture system geometry and their implications for fluid flow in fractured hydrocarbon reservoirs. Pet Geosci 5:373384. https://doi.org/10.1144/petgeo.5.4.373

Odling NE, West LJ, Hartmann S, Kilpatrick A (2013) Fractional flow in fractured chalk; a flow and tracer test revisited. Journal of contaminant hydrology 147:96-111

Olivarius M, Nielsen LH (2016) Triassic paleogeography of the greater eastern Norwegian-Danish basin: constraints from provenance analysis of the Skagerrak Formation. Mar Pet Geol 69:168-182. https:// doi.org/10.1016/j.marpetgeo.2015.10.008

Olsson WA, Lorenz JC, Cooper SP (2004) A mechanical model for multiply-oriented conjugate deformation bands. J Struct Geol 26: 325-338. https://doi.org/10.1016/S0191-8141(03)00101-9

Pokar M, West LJ, Odling NE (2006) Petrophysical characterization of the Sherwood sandstone from East Yorkshire, UK. Geol Soc Spec Publ 263:103-118. https://doi.org/10.1144/GSL.SP.2006.263.01.05

Price M, Morris B, Robertson A (1982) A study of intergranular and fissure permeability in chalk and Permian aquifers, using doublepacker injection testing. J Hydrol 54:401-423. https://doi.org/10. 1016/0022-1694(82)90165-2

Quinn PM, Parker BL, Cherry JA (2011) Using constant head step tests to determine hydraulic apertures in fractured rock. J Contam Hydrol 126(1-2):85-99. https://doi.org/10.1016/j.jconhyd.2011.07.002

Ramingwong T (1974) Hydrogeology of the Keuper Sandstone in the Droitwich syncline area-Worcestershire. PhD Thesis, University of Birmingham, UK

Ren S, Gragg S, Zhang Y, Carr BJ, Yao G (2018) Borehole characterization of hydraulic properties and groundwater flow in a crystalline fractured aquifer of a headwater mountain watershed, Laramie Range, Wyoming. J Hydrol 561:780-795. https://doi.org/10.1016/ j.jhydrol.2018.04.048

Rivers CN, Barrett MH, Hiscock KM, Dennis PF, Feast NA, Lerner DN (1996) Use of nitrogen isotopes to identify nitrogen contamination of the Sherwood Sandstone aquifer beneath the city of Nottingham, United Kingdom. Hydrogeol J 4(1):90-102. https://doi.org/10. 1007/s 100400050099

Ryseth A, Fjellbirkeland H, Osmundsen IK, Skålnes Å, Zachariassen E (1998) High-resolution stratigraphy and seismic attribute mapping of a fluvial reservoir: Middle Jurassic Ness Formation, Oseberg Field. AAPG Bull 82(9):1627-1651

Schmid S, Worden RH, Fisher QJ (2006) Sedimentary facies and the context of dolocrete in the lower Triassic Sherwood Sandstone Group: Corrib Field west of Ireland. Sediment Geol 187:205-227. https://doi.org/10.1016/j.sedgeo.2005.12.028

Schwartz MO (2012) Modelling groundwater contamination above a nuclear waste repository at Gorleben, Germany. Hydrogeol J 20(3): 533-546. https://doi.org/10.1007/s10040-011-0825-z

Schwartz MO (2018) The new Wallula $\mathrm{CO}_{2}$ project may revive the old Columbia River basalt (western USA) nuclear-waste repository project. Hydrogeol J 26(1):3-6. https://doi.org/10.1007/s10040-0171632-y

Seymour KJ, Ingram JA, Gebbett SJ (2006) Structural controls on groundwater flow in the Permo-Triassic sandstones of NW England. Geol Soc Spec Publ 263:169-185. https://doi.org/10. 1144/GSL.SP.2006.263.01.09

Shand P, Edmunds WM, Lawrence AR, Smedley PL, Burke S (2007) The natural (baseline) quality of groundwater in England and Wales. Report RR/07/06, British Geological Survey, Nottingham, UK

Shutes RBE, Revitt DM, Mungur AS, Scholes LNL (1997) The design of wetland systems for the treatment of urban run off. Water Sci Technol 35:19-25

Smedley PL, Edmunds WB (2002) Redox patterns and trace-element behavior in the East Midlands Triassic Sandstone aquifer, UK. Groundwater 40:44-58. https://doi.org/10.1111/j.1745-6584.2002. tb02490.x

Smith SA (1990) The sedimentology and accretionary styles of an ancient gravel-bed stream: the Budleigh Salterton pebble beds (lower Triassic), Southwest England. Sediment Geol 67:199-219. https:// doi.org/10.1016/0037-0738(90)90035-R

Steel RJ, Thompson DB (1983) Structures and textures in Triassic braided stream conglomerates ('bunter' pebble beds) in the Sherwood Sandstone group, north Staffordshire, England. Sedimentology 30: 341-367. https://doi.org/10.1111/j.1365-3091.1983.tb00677.x

Sternlof KR, Chapin JR, Pollard DD, Durlofsky LJ (2004) Permeability effects of deformation band arrays in sandstone. AAPG Bull 88: 1315-1329

Streetly M, Chakrabarty C, McLeod R (2000) Interpretation of pumping tests in the Sherwood Sandstone Group, Sellafield, Cumbria, UK. Q J Eng Geol Hydrogeol 33(4):281-299. https://doi.org/10.1144/ qjegh.33.4.281

Strong GE (1993) Diagenesis of Triassic Sherwood Sandstone Group rocks, Preston, Lancashire, UK: a possible evaporitic cement precursor to secondary porosity? Geol Soc Spec Publ 73:279-289. https://doi.org/10.1144/GSL.SP.1993.073.01.17

Strong GE, Milodowski AE, Pearce JM, Kemp SJ, Prior SV, Morton AC (1994) The petrology and diagenesis of Permo-Triassic rocks of the Sellafield area, Cumbria. Proc Yorkshire Geol Polytech Soc 50:7789. https://doi.org/10.1144/pygs.50.1.77

Swanson SK, Bahr JM, Bradbury KR, Anderson KM (2006) Evidence for preferential flow through sandstone aquifers in southern Wisconsin. Sediment Geol 184:331-342. https://doi.org/10.1016/j. sedgeo.2005.11.008

Tellam JH, Barker RD (2006) Towards prediction of saturated-zone pollutant movement in groundwaters in fractured permeable-matrix aquifers: the case of the UK Permo-Triassic sandstones. Geol Soc Spec Publ 263:1-48. https://doi.org/10.1144/GSL.SP.2006.263.01. 01

Tesmer M, Möller P, Wieland S, Jahnke C, Voigt H, Pekdeger A (2007) Deep reaching fluid flow in the North East German Basin: origin and processes of groundwater salinisation. Hydrogeol J 15(7):12911306. https://doi.org/10.1007/s10040-007-0176-y

Thompson DB (1970) Sedimentation of the Triassic (Scythian) red pebbly sandstones in the Cheshire Basin and its margins. Geol J 7:183216. https://doi.org/10.1002/gj.3350070111 
Thompson RP, Leach BA (1985) Strain-stiffness relationship for weak sandstone rock. Proceedings of the 11th Int. Conf. on Soil Mechanics and Foundation Engineering, San Francisco, August 1985

Tindall S, Eckert A (2015) Geometric and mechanical-stiffness controls on jointing in cataclastic deformation bands. J Struct Geol 77:126137. https://doi.org/10.1016/j.jsg.2015.05.008

Torabi A, Fossen H, Braathen A (2013) Insight into petrophysical properties of deformed sandstone reservoirs. AAPG Bull 97(4):619-637. https://doi.org/10.1306/10031212040

Trevena AS, Clark RA (1986) Diagenesis of sandstone reservoirs of Pattani Basin, Gulf of Thailand. AAPG Bull 70:299-308

Tsang CF, Barnichon JD, Birkholzer J, Li XL, Liu HH, Sillen X (2012) Coupled thermo-hydro-mechanical processes in the near field of a high-level radioactive waste repository in clay formations. Int $\mathbf{J}$ Rock Mech Min Sci 49:31-44. https://doi.org/10.1016/j.ijrmms. 2011.09.015

Tueckmantel C, Fisher QJ, Grattoni CA, Aplin AC (2012) Single-and two-phase fluid flow properties of cataclastic fault rocks in porous sandstone. Mar Pet Geol 29:129-142. https://doi.org/10.1016/j. marpetgeo.2011.07.009

Tueckmantel C, Fisher QJ, Knipe RJ, Lickorish H, Khalil SM (2010) Fault seal prediction of seismic-scale normal faults in porous sandstone: a case study from the eastern Gulf of Suez Rift, Egypt. Mar Pet Geol 27(2):334-350. https://doi.org/10.1016/j.marpetgeo.2009. 10.008

Turner P, Ixer RA (1977) Diagenetic development of unstable and stable magnetization in the St. Bees Sandstone (Triassic) of northern England. Earth Planet Sci Lett 34(1):113-124. https://doi.org/10. 1016/0012-821X(77)90112-1

Vengosh A, Jackson RB, Warner N, Darrah TH, Kondash A (2014) A critical review of the risks to water resources from unconventional shale gas development and hydraulic fracturing in the United States. Environ Sci Technol 48(15):8334-8348. https://doi.org/10.1021/ es405118y

Voss CI, Andersson J (1993) Regional flow in the Baltic shield during Holocene coastal regression. Groundwater 31(6):989-1006. https:// doi.org/10.1111/j.1745-6584.1993.tb00873.x

Wakefield OJW, Hough E, Peatfield AW (2015) Architectural analysis of a Triassic fluvial system: the Sherwood Sandstone of the East Midlands Shelf, UK. Sediment Geol 327:1-13. https://doi.org/10. 1016/j.sedgeo.2015.07.006

Walsby JC, Lowe GJ, Forster A (1993) The engineering geology of weak rock. Balkema, Rotterdam, The Netherlands

Waugh B (1970) Formation of quartz overgrowths in the Penrith sandstone (lower Permian) of Northwest England as revealed by scanning electron microscopy. Sedimentology 14:309-320. https://doi. org/10.1111/j.1365-3091.1970.tb00197.x
Waugh B (1973) The distribution and formation of Permo-Triassic Red Beds. Pet Geol Mem 2:678-693

Wealthall GP, Steele A, Bloomfield JP, Moss RH, Lerner DN (2001) Sediment filled fractures in the Permo-Triassic sandstones of the Cheshire Basin: observations and implications for pollutant transport. J Contam Hydrol 50:41-51. https://doi.org/10.1016/S01697722(01)00104-8

West G (1979) Strength properties of bunter sandstone. Tunnels Tunnelling 7(7):27-29

Whithworth LJ, Turner AJ (1989) Rock socket piles in the Sherwood Sandstone of central Birmingham. In: Proceedings of the Conference on Piling and Deep Foundations. Institution of Civil Engineers, London, pp 327-334

Wilson JT (1963) Continental drift. Sci Am 208:86-103

Wilson MP, Worrall F, Davies RJ, Hart A (2017) Shallow aquifer vulnerability from subsurface fluid injection at a proposed shale gas hydraulic fracturing site. Water Resour Res 53(11):9922-9940. https:// doi.org/10.1002/2017WR021234

Witherspoon PA (1996) Geological problems in radioactive waste isolation-second worldwide review. Report 38915, Lawrence Berkeley Laboratory, Berkeley, CA

Wong TF, David C, Zhu W (1997) The transition from brittle faulting to cataclastic flow in porous sandstones: mechanical deformation. J Geophys Res Solid Earth 102:3009-3025. https://doi.org/10.1029/ 96JB03281

Worden RH, Benshatwan MS, Potts GJ, Elgarmadi SM (2016) Basinscale fluid movement patterns revealed by veins: Wessex Basin, UK. Geofluids 16:149-174. https://doi.org/10.1111/gfl.12141

Worthington SR, Davies GJ, Alexander EC Jr (2016) Enhancement of bedrock permeability by weathering. Earth Sci Rev 160:188-202. https://doi.org/10.1016/j.earscirev.2016.07.002

Yates PGJ (1992) The material strength of sandstones of the Sherwood Sandstone Group of north Staffordshire with reference to microfabric. Q J Eng Geol Hydrogeol 25:107-113. https://doi.org/ 10.1144/GSL.QJEG.1992.025.02.04

Yuan G, Cao Y, Jia Z, Gluyas J, Yang T, Wang Y, Xi K (2015) Selective dissolution of feldspars in the presence of carbonates: the way to generate secondary pores in buried sandstones by organic $\mathrm{CO} 2$. Mar Pet Geol 60:105-119

Zheng SY, Corbett PWM, Emery A (2003) Geological interpretation of well test analysis: a case study from a fluvial reservoir in the Gulf of Thailand. J Pet Geol 26(1):49-64. https://doi.org/10.1111/j.17475457.2003.tb00017.x

Zheng SY, Corbett PW, Ryseth A, Stewart G (2000) Uncertainty in well test and core permeability analysis: a case study in fluvial channel reservoirs, northern North Sea, Norway. AAPG Bull 84:1929-1954 